\title{
Morphology and evolution of scopula, pseudoscopula and claw tufts in Mygalomorphae (Araneae)
}

\author{
F. Pérez-Miles ${ }^{1}$ · J. P. L. Guadanucci ${ }^{2}$ J. P. Jurgilas ${ }^{2} \cdot$ R. Becco ${ }^{1} \cdot$ \\ C. Perafán ${ }^{1}$ (1)
}

Received: 27 January 2017 / Revised: 4 July 2017 / Accepted: 9 July 2017 / Published online: 22 July 2017

(C) Springer-Verlag GmbH Germany 2017

\begin{abstract}
We studied the morphology of scopula, claw tufts and a scopula-like feature (pseudoscopula) of tarsi on representatives of all Mygalomorphae spider families. The pseudoscopula is constituted by groups of non-microtriched conical setae. The taxonomic distribution of all these features was studied and mapped on a recent phylogeny of Mygalomorphae and the association of them with the lifestyles of the spiders was analyzed. Adhesive setae, as well as some other setal types found on ventral tarsi are described and characterized. The adhesive face of setae varied in the orientation in different parts of the tarsi, and this variation is more conspicuous in the spiders which only have claw tufts or scopula. We found an association of adhesive scopulae and claw tufts with burrower/cursorial or thin wafer lid trapdoor mygalomorphs as suggested for free hunter spiders, but we found that the pseudoscopula is associated with males of some trap-door and some weavers mygalomorphs. The presence of pseudoscopula widely extended among Mygalomorphae seems to be ancestral for the infraorder. The setal morphology of pseudoscopula suggests chemosensorial function; sparse chemosensory setae were also found in almost all Mygalomorphae. The
\end{abstract}

Electronic supplementary material The online version of this article (doi:10.1007/s00435-017-0364-9) contains supplementary material, which is available to authorized users.

\section{Perafán}

caperafanl@gmail.com

1 Sección Entomología, Facultad de Ciencias, Universidad de la República, Iguá 4225, Montevideo, Uruguay

2 Departamento de Zoologia, Instituto de Biociências, UNESP, Av. 24A 1515, Bela Vista, Rio Claro, São Paulo 13506-900, Brazil morphology, functions and evolution of scopula, claw tufts and pseudoscopula are discussed.

Keywords Copulation · Locomotion · Mygalomorph · Prey-capture $\cdot$ Setae-morphology

\section{Introduction}

Spiders are one of the most successful terrestrial predators among arthropods. Some families utilize webs for prey capture but many other families are free hunters, including most Mygalomorphae (Cardoso et al. 2011). The ability of spiders to capture prey or adhere to smooth surfaces for climbing was explained by the specialized setae with many hair-like protuberances of the cuticle, called setules (Kesel et al. 2003) or microtrichia (Richards and Richards 1979). The adhesive setae are arranged along the tarsi and metatarsi (scopula) and or under the claws (claw tufts).

The morphology of sticky setae, functions, mechanics and association with lifestyle was exhaustively studied (Homann 1957; Foelix and Chu-Wang 1975; Hill 1977; Rovner 1978; Kesel et al. 2003, 2004; Niederegger and Gorb 2006, Varenberg et al. 2010; Foelix 2011; Foelix et al. 2012; Keane et al. 2012; Wolff and Gorb 2012a, b, 2015; Wolff et al. 2013; Niederegger 2013; Wohlfart et al. 2014; Lapinski et al. 2015; Pérez-Miles et al. 2015); these studies mostly focused on Araneomorphae. However, fine structure and function of adhesive setae in mygalomorphs are severely understudied. Several authors stressed on the importance of adhesive setae in two functions: prey capture and locomotion (Homann 1957; Rovner 1978, 1980; Dunlop 1994; Foelix 2011; Pekar et al. 2011; Foelix et al. 2012; Niederegger 2013; Wolff and 
Gorb 2012a, 2015; Wolff et al. 2013; Lapinski et al. 2015; Eggs et al. 2015).

For more than a century, the morphology and arrangement of scopula has been widely used in the taxonomy of Mygalomorphae to diagnose families, subfamilies and even genera (Simon 1892). Pérez-Miles (1994) analyzed the association between scopula condition and body size in theraphosids and Guadanucci (2005) studied the phylogeny of scopula condition in Ischnocolinae. Recently, Wolff et al. (2013) associated the adhesive pads with cursorial lifestyle in Mygalomorphae, being absent in some trapdoor spiders and those that build sheet or funnel webs, and it was codified in a similar way by Bond et al. (2012). However, Raven (1985) in his comprehensive revision of Mygalomorphae reported the scopula also in trapdoor or weaver families such as Actinopodidae, Antrodiaetidae, Atypidae, Ctenizidae, Hexathelidae (Atrax) and Idiopidae.

To elucidate if the above-mentioned scopula represents the same (homologous?) feature in different mygalomorph families, we performed a comparative scanning electronic microscope (SEM) study of the morphology of setae on distal and ventral tarsi (scopula and claw tufts) of representatives of all mygalomorph families. We also mapped these features on a recent phylogeny of the Mygalomorphae (Bond et al. 2012) comparing with lifestyles of the spiders. Our questions were: (1) Is there any ultrastructural variation in scopula and claw tufts among mygalomorphs? (2) Which are the patterns of arrangement of setae in mygalomorph groups? (3) Are the types of setae similar to those reported for araneomorphs? (4) Is there any association between tarsal features and the lifestyle of the spiders? (5) What are the possible evolutionary trends of these features in the Mygalomorphae? Our main objective is to understand the relationships between morphology, function, lifestyle and evolution of mygalomorph ventral tarsal setae.

We found comparable adhesive setae in Mygalomorphae to those of Araneomorphae. We observed that trapdoor and some web-building mygalomorphs have setae on a similar arrangement as in the scopula but with different non microtriched setae (called here as pseudoscopula); they have opposite anterior-posterior gradation than proposed for scopulae of other mygalomorphs (Raven 1985) and also they present sexual dimorphism, present only in males. Our results agree with the prey capture and locomotion functions for microtriched scopula and claw tufts but suggest that the pseudoscopula is composed by sensorial setae. The greater development of pseudoscopula on male hind legs suggests that it can also contribute to the stability for copulation position. The evolution of these features and their association with lifestyle factors are discussed.

\section{Materials and methods}

\section{Taxon sampling and morphological studies}

We examined representatives of all Mygalomorphae families (Table 1 and voucher list in supplementary material). Tarsi of legs were studied by stereo microscopy and scanning electronic microscopy (SEM). Additional morphological information was taken from photographs (taken by L. Montes de Oca) of material from the University of Auburn (USA).

We documented the presence of pads of setae with the appearance of scopula or claw tufts. Adhesive setae were defined as setae with areas covered by spatulated microtrichia (Wolff and Gorb 2012a). The position of the adhesive face of setae was defined as the face with dense microtrichia. The types of adhesive setae were compared with the nomenclature of Wolff et al. (2013) and Lapinski et al. (2015) (Table 2). For the recognition of claw tufts we followed the definitions of Wolff et al. (2013), Ramírez (2014) and Labarque et al. (2017). For the recognition of scopula we considered a dense, regular array of adhesive setae. The arrangement of adhesive setae (scopula and claw tufts) was registered and also features with the appearance of scopula but without microtriched setae (pseudoscopula).

SEM studies were performed on air-dehydrated from alcohol preserved tarsi with a Jeol JSM-5900LV microscope of the Servicio de Microscopía, Facultad de Ciencias, Montevideo, Uruguay and with a Hitachi TM-1000 microscope of the Laboratório de Microscopia Eletronica, Instituto de Biociências, Rio Claro, Universidade Estadual Paulista (UNESP).

\section{Analysis}

Phylogeny is based on Bond et al. (2012); and lifestyle characterization follows Bond and Opell (2002) and was also taken from an exhaustive analysis of the literature and personal observations. We mapped the following characters: (1) lifestyle: 0 = burrower; $1=$ funnel or sheet web; $2=$ trapdoor; when a genus includes both categories (e.g. trapdoor and funnel web spiders) or the lifestyle is doubtful it was codified as not applicable. (2) Adhesive setae (including few or sparse): $0=$ absent; $1=$ present. (3) Males with a tarsal feature with the appearance of scopula: $0=$ absent, $1=$ with predominance of adhesive setae (scopula), 2 = with predominance of chemosensory setae (pseudoscopula), 3 = presence of adhesive and chemosensory setae with no evident predominance of any of them.

To map the presence of adhesive setae and lifestyle condition, we traced character history on the total evidence tree (Bond et al. 2012, accessed from Dryad Data repository http://dx.doi.org/10.5061/dryad.7sq2j (DOCX) with 
Table 1 Mygalomorph species examined and type of setae and structure present on ventral tarsus

\begin{tabular}{|c|c|c|c|c|c|c|c|}
\hline \multirow[t]{2}{*}{ Family } & \multirow[t]{2}{*}{ Species } & \multicolumn{2}{|c|}{$\begin{array}{l}\text { Scopula/pseudoscopula, } \\
\text { predominance of setae } \\
\text { type: }\end{array}$} & \multicolumn{2}{|c|}{$\begin{array}{l}\text { Anterior/posterior } \\
\text { gradations (male) }\end{array}$} & \multirow[t]{2}{*}{$\begin{array}{l}\text { Few setae type (alone or } \\
\text { mixed with main structure) }\end{array}$} & \multirow[t]{2}{*}{ Claw tufts } \\
\hline & & Male & Female & Anterior & Posterior & & \\
\hline Liphistidae & Liphistius sp. & che & - & + & & - & No \\
\hline \multirow[t]{3}{*}{ Actinopodidae } & Actinopus rufipes & che & - & & + & - & No \\
\hline & Actinopus spp. & che & - & & + & - & No \\
\hline & Missulena sp. & che & $?$ & & + & - & No \\
\hline \multirow[t]{2}{*}{ Antrodiaetidae } & Antrodiaetus sp. & che & - & & + & - & No \\
\hline & Aliatypus californicus & che & - & & + & - & No \\
\hline \multirow[t]{2}{*}{ Atypidae } & Atypus affinis & che & - & & + & - & No \\
\hline & Sphodros sp. & che & - & & & - & No \\
\hline \multirow[t]{21}{*}{ Barychelidae } & Ammonius sp. & - & - & + & & che & Yes \\
\hline & Encyocrypta aureco & adh & $?$ & & & che & Yes \\
\hline & Idioctis helva & adh & $?$ & & & che & Yes \\
\hline & Idiommata sp. & adh & $?$ & & & che & Yes \\
\hline & Mandjelia sp. & adh & adh & & & che & Yes \\
\hline & Moruga fuliginea & $?$ & adh & & & - & Yes \\
\hline & Nihoa sp. & adh & adh & & & che & Yes \\
\hline & Neodiplothele martinsi & adh & adh & & & che & Yes \\
\hline & Orstom chazedui & $?$ & adh & & & - & Yes \\
\hline & Ozicrypta sp. & adh & adh & & & che & Yes \\
\hline & Pisenor sp. & $?$ & adh & & & - & Yes \\
\hline & Psalistops corazali & $?$ & adh & & & - & Yes \\
\hline & Questocrypta goloboffi & $?$ & adh & & & - & Yes \\
\hline & Rhianodes sp. & $?$ & adh & & & - & Yes \\
\hline & Sason colemani & $?$ & adh & & & - & Yes \\
\hline & Seqocrypta jakara & $?$ & adh & & & - & Yes \\
\hline & Sipalolasma sp. & $?$ & adh & & & - & Yes \\
\hline & Strophaeus sp. & $?$ & adh & & & che & Yes \\
\hline & Synothele moonabie & $?$ & adh & & & - & Yes \\
\hline & Trittame kochi & $?$ & adh & & & - & Yes \\
\hline & Tungari kenwayae & $?$ & adh & & & - & Yes \\
\hline \multirow[t]{6}{*}{ Ctenizidae } & Conothele sp. & che & - & + & & - & No \\
\hline & Ummidia sp. & che & - & + & & - & No \\
\hline & Bothriocyrtum californicum & $?$ & - & & & - & No \\
\hline & Cyclocosmia spp & che & $?$ & & & - & No \\
\hline & Hebestatis spp. & che & $?$ & & + & - & No \\
\hline & Stasimopus sp. & che & $?$ & & + & - & No \\
\hline \multirow[t]{9}{*}{ Cyrtaucheniidae } & Fufius sp. & che & adh & + & & - & No \\
\hline & Acontius sp. & che & adh & + & & adh & No \\
\hline & Rhytidicolus sp. & che & adh & + & & - & No \\
\hline & Bolostromus sp. & che & adh & + & & - & No \\
\hline & Ancylotrypa pretoriae & $?$ & adh & & & - & No \\
\hline & Anemesia sp. & $?$ & adh & & & - & No \\
\hline & Angka hexops & $\mathrm{adh}$ & $?$ & + & & - & No \\
\hline & Kiama lachrymoides & $?$ & adh & & & - & No \\
\hline & Cyrtauchenius spp. & $?$ & adh & & & $?$ & No \\
\hline
\end{tabular}


Table 1 continued

\begin{tabular}{|c|c|c|c|c|c|c|c|}
\hline \multirow{2}{*}{$\begin{array}{l}\text { Family } \\
\text { Dipluridae }\end{array}$} & \multirow{2}{*}{$\begin{array}{l}\text { Species } \\
\text { Diplura sp. }\end{array}$} & \multicolumn{2}{|c|}{$\begin{array}{l}\text { Scopula/pseudoscopula, } \\
\text { predominance of setae } \\
\text { type: }\end{array}$} & \multicolumn{2}{|c|}{$\begin{array}{l}\text { Anterior/posterior } \\
\text { gradations (male) }\end{array}$} & \multirow[t]{2}{*}{$\begin{array}{l}\text { Few setae type (alone or } \\
\text { mixed with main structure) }\end{array}$} & \multirow[t]{2}{*}{ Claw tufts } \\
\hline & & - & adh/che & + & & & \\
\hline & Ischnothele annulata & che & - & & + & - & No \\
\hline & Linothele sp. & - & adh/che & + & & - & No \\
\hline & Trechona sp. & - & adh/che & + & & - & No \\
\hline & Euagrus sp. & $?$ & - & & & - & No \\
\hline & Australothele jamesoni & che & - & & + & - & No \\
\hline & Stenygrocercus sp. & che & - & + & & - & No \\
\hline & Cethegus sp. & che & - & & + & - & No \\
\hline & Caledothele simoni & che & $?$ & & & - & No \\
\hline & Namirea sp. & che & - & & + & - & No \\
\hline \multirow[t]{3}{*}{ Euctenizidae } & Aptostichus simus & - & $?$ & + & & adh/che & No \\
\hline & Myrmekiaphila sp. & che & $?$ & + & & adh* & No \\
\hline & Eucteniza mexicana & che & $?$ & + & & - & No \\
\hline \multirow[t]{6}{*}{ Hexathelidae } & Hexathele sp. & $?$ & - & & & - & No \\
\hline & Paraembolides boycei & che & - & & + & - & No \\
\hline & Hadronyche sp. & che & - & + & & - & No \\
\hline & Teranodes sp. & che & - & & + & - & No \\
\hline & Bymainiella monteithi & che & - & & + & - & No \\
\hline & Scotinoecus cinereopilosus & $?$ & - & & & $?$ & No \\
\hline \multirow[t]{5}{*}{ Idiopidae } & Idiops clarus & che & - & & + & - & No \\
\hline & Homogona pulleinei & $?$ & - & & & - & No \\
\hline & Aganippe sp. & che & adh & + & & - & No \\
\hline & Euoplos variabilis & che & adh & + & & adh* & No \\
\hline & Misgolas spp. & $?$ & adh & & & - & No \\
\hline \multirow[t]{2}{*}{ Mecicobothriidae } & Mecicobothrium thorelli & - & - & & & che & No \\
\hline & Hexura picea & $?$ & - & & & - & No \\
\hline \multirow[t]{6}{*}{ Microstigmatidae } & Envia $\mathrm{sp}$ & - & - & & & - & No \\
\hline & Envia garciai & - & $?$ & & & - & No \\
\hline & Xenonemesia platense & - & $?$ & & & adh/che & \\
\hline & Xenonemesia ottii & che & $?$ & + & & adh & No \\
\hline & Pseudonemesia tabiskey & - & $?$ & & & - & No \\
\hline & Microstigmata spp. & $?$ & - & & & - & No \\
\hline \multirow[t]{4}{*}{ Migidae } & Heteromigas dovei & $?$ & - & & & - & No \\
\hline & Moggridgea australis & $?$ & - & & & - & No \\
\hline & Migas nitens & che & - & & + & - & No \\
\hline & Calathotarsus simoni & $?$ & - & & & - & No \\
\hline \multirow[t]{11}{*}{ Nemesiidae } & Acanthogonatus incursus & $?$ & adh & & & $?$ & No \\
\hline & Acanthogonatus minimus & che & $?$ & + & & $?$ & No \\
\hline & Acantogonathus tacuariensis & $\mathrm{adh} / \mathrm{che}$ & adh/che & + & & - & No \\
\hline & Chenistonia $\mathrm{sp.}$ & $\mathrm{adh} / \mathrm{che}$ & $\mathrm{adh} / \mathrm{che}$ & + & & - & No \\
\hline & Nemesia sp. & $\mathrm{adh} / \mathrm{che}$ & $?$ & + & & - & No \\
\hline & Aname sp. & $\mathrm{adh} / \mathrm{che}$ & $?$ & + & & - & No \\
\hline & Lycinus sp. & adh/che & $?$ & + & & - & No \\
\hline & Prorachias itapety & $\mathrm{adh} / \mathrm{che}$ & $\mathrm{adh} / \mathrm{che}$ & + & & - & No \\
\hline & Stanwellia sp. & $\mathrm{adh} / \mathrm{che}$ & adh/che & + & & - & No \\
\hline & Stenoterommata sp. & $\mathrm{adh} / \mathrm{che}$ & $\mathrm{adh} / \mathrm{che}$ & + & & - & No \\
\hline & Damarchus sp. & $?$ & adh & & & $?$ & No \\
\hline
\end{tabular}


Table 1 continued

\begin{tabular}{|c|c|c|c|c|c|c|}
\hline \multirow[t]{2}{*}{ Family } & \multirow{2}{*}{$\begin{array}{l}\text { Species } \\
\text { Ixamatus musgravei }\end{array}$} & \multicolumn{2}{|c|}{$\begin{array}{l}\text { Scopula/pseudoscopula, } \\
\text { predominance of setae } \\
\text { type: }\end{array}$} & \multirow{2}{*}{$\begin{array}{l}\text { Anterior/posterior } \\
\text { gradations (male) } \\
+\end{array}$} & \multirow{2}{*}{$\begin{array}{l}\text { Few setae type (alone or } \\
\text { mixed with main structure) } \\
\text { ? }\end{array}$} & \multirow{2}{*}{$\begin{array}{l}\text { Claw tufts } \\
\text { No }\end{array}$} \\
\hline & & che & adh & & & \\
\hline & Raveniola virgata & $?$ & adh & & $?$ & No \\
\hline & Spiroctenus sp. & che & $?$ & + & $?$ & \\
\hline & Xamiatus rubrifrons & $?$ & adh & & $?$ & No \\
\hline & Teyl sp. & $\mathrm{adh} / \mathrm{che}$ & $?$ & + & & No \\
\hline & Calisoga sp. & $\mathrm{adh} / \mathrm{che}$ & $?$ & + & & \\
\hline \multirow[t]{22}{*}{ Theraphosidae } & Avicularia sp. & adh & adh & + & che & Yes \\
\hline & Ami spp. & adh & adh & + & che & Yes \\
\hline & Aphonopelma seemannii & adh & adh & + & che & Yes \\
\hline & Catumiri chicaoi & $?$ & adh & & $?$ & Yes \\
\hline & Eupalaestrus weijenberghi & adh & adh & + & che & Yes \\
\hline & Grammostola anthracina & adh & adh & + & che & Yes \\
\hline & Guyruita spp. & adh & adh & + & che & Yes \\
\hline & Hapalopus formosus & adh & adh & + & che & Yes \\
\hline & Holothele longipes & adh & adh & + & che & Yes \\
\hline & Homoeomma uruguayense & adh & adh & + & che & Yes \\
\hline & Iridopelma hirsutum & adh & adh & + & che & Yes \\
\hline & Oligoxystre diamantinensis & adh & $?$ & + & che & Yes \\
\hline & Sickius longibulbi & adh & adh & + & che & Yes \\
\hline & Tmesiphantes perp & adh & $?$ & + & che & Yes \\
\hline & Heterothele sp. & adh & adh & + & che & Yes \\
\hline & Plesiopelma longisternale & adh & adh & & che & Yes \\
\hline & Psalmopoeus ecclesiasticus & adh & adh & & che & Yes \\
\hline & Pterinochilus murinus & adh & adh & + & che & Yes \\
\hline & Stromatopelma sp. & adh & $?$ & + & che & Yes \\
\hline & Trichopelma sp. & $?$ & adh & & $?$ & Yes \\
\hline & Typhlochaena paschoali & adh & $?$ & + & che & Yes \\
\hline & Vitalius sp. & adh & $?$ & + & che & Yes \\
\hline \multirow[t]{2}{*}{ Paratropididae } & Paratropis sp. & che & $?$ & + & - & No \\
\hline & Melloina sp. & $?$ & - & & - & Yes \\
\hline
\end{tabular}

adh adhesive setae, che chemosensory setae, $a d h / c h e$ presence of adhesive and chemosensory setae with no clear predominance of any of them, plus sign denser, question mark not directly examined, - absent

*Restricted to apical region

Mesquite (Maddison and Maddison 2017) using parsimony ancestral state reconstruction.

\section{Results}

\section{Scopula, pseudoscopula and claw tuft setae}

We found five morphological types of setae forming scopulae and claw tufts in Mygalomorphae. Adhesive setae types are present in claw tufts, lateral bands of scopulae in species with divided scopula, and throughout the ventral face of tarsi in species with entire scopula, mostly in burrower/cursorial families. Other types of setae found are conical and were mainly found in the longitudinal median line of divided scopulae and in the transitional zone between scopula and claw tufts. We found another type of non microtriched setae forming a scopula-like structure (named here as pseudoscopula) or fewer and sparse on tarsi of almost all Mygalomorphae. We also found important differences in the arrangement and density variation of both types of setae from proximal to distal part of tarsi as well as in the anterior-posterior gradations among groups.

\section{Lamellate setae}

Lamellate setae are widespread in adhesive scopula and claw tufts. They are subcylindrical with the distal third 
Table 2 Comparison between the setae found in Mygalmorphae with the nomenclature used by Rovner (1978), Foelix et al. (2010), Wolff and Gorb (2012a) and Lapinski et al. (2015)

\begin{tabular}{lllll}
\hline Mygalomorphae (this paper) & Rovner (1978) & Foelix et al. (2010) & Wolff et al. (2013) & Lapinski et al. (2015) \\
\hline Lamellate setae & A & - & AS-II & I \\
Lamellate-crested setae & - & - & AS-I & IIb \\
Non lamellate setae & - & - & FS-II & IV \\
Conical setae & B & - & - & VI \\
Non microtriched setae & - & Idiops pilorus & - & - \\
\hline
\end{tabular}

widened and apically curved (Fig. 1). The basal third of the setae lacks lateral extensions, the median third has sparse microtrichia and the apical third is densely covered by spatulate microtrichia mainly on one side (adhesive face). The orientation of the adhesive face of setae varies in different parts of the tarsus. In groups which have adhesive scopula and claw tufts, the adhesive face is on the ventral side of claw tuft setae (the side normally directed towards the body) and on the dorsal side of the setae on the scopula (the side directed distally). On the tip of the legs (apical scopula or claw tufts) occurs a slight rotation of the setae with the adhesive face oriented to the axis of the leg (Fig. 2). In species which only posses claw tufts (Melloina sp.) the adhesive face of setae is oriented ventrally in apical setae while are oriented to the axis of the leg in proximal setae (Fig. 3c).

The microtrichia on the adhesive face are lateral extensions of the setae, subcylindrical, with the basis slightly widened and the apex widened and laterally flattened (Figs. 3d and 4). The shape of spatulae on microtrichia varies from sub-circular (e.g. Plesiopelma longisternale, Fig. 4b), sub-triangular (e.g. Eupalaestrus weijenberghi, Fig. 4d) or sub-rhomboid (Pterinochilus murinus, Fig. 4f). Distal microtrichia on the non-adhesive face are longer and more curved than those on the adhesive face and are not distally widened (Fig. 5). These microtrichia are arranged in approximately longitudinal bands. Microtrichia of the adhesive face are more dense than that in the non-adhesive face.

Lamellate setae are present on claw tufts, predominate in the entire scopula and form the lateral bands of the divided scopula (see Pérez-Miles 1994; Guadanucci 2005). Claw tuft setae were more variable in length than those of scopula.

We found this type of setae present in barychelids, Melloina (Paratropididae) and theraphosids. Particularly in Aviculariinae the microtrichia on the adhesive face are modified; flattened and fused on their bases and arranged in a band pattern (Fig. $4 \mathrm{~g}$, h). In the barychelid genus Strophaeus we found that the female lacks claw tufts on the palp, while usually theraphosid and barychelid females have palpal claw tufts. This female has palpal setae with adhesive faces oriented in opposite directions in different parts of the scopula (ventral side in distal region and dorsal side in proximal region), as indicated for leg adhesive pads (Fig. 2h).

\section{Lamellate-crested setae}

This type of setae is similar to the lamellate type but differs by an apical longer conspicuous microtrichia. This variation was observed on scopulae of Avicularia sp., Plesiopelma longisternale and Homoeomma uruguayense (Figs. 1d, g and 4a).

\section{Lance-shaped setae}

These setae are subcylindrical with the distal third curved and not so widened as in the lamellate type (Figs. 6a-f, 7a-e); the apex is sharpened. The proximal half of the setae completely lacks lateral extensions as well as the non-adhesive face. Only the distal half, on the adhesive face, is densely covered by microtrichia (Figs. 6b, d, f, 7b, e). As in the lamellate type, the adhesive face is oriented dorsally on setae of proximal scopula and ventrally in apical scopula (e.g. Figs. 6a, b, c, d, 7a, b, c, d). Microtrichia are subcylindrical with the apex widened but not as conspicuous as in the lamellate setae. The subapical part of the seta is abruptly thinned and lacks microthrichia (Figs. 6b, d, 7b, e); in this group the non-adhesive parts of the setae are mainly longitudinally striated (e.g. Fig. 7e).

We found this type of setae in nemesiids (Fig. 7a, b), some idiopids (Aganippe, Euoplos), microstigmatid Xenonemesia (Fig. 8), cyrtaucheniids (Fig. 6a-f), some diplurids (Diplura, Trechona, Linothele) (Fig. 7c-h) and some euctenizids (Fig. 10e, g). These families only have scopula and lack claw tufts. It is remarkable that adhesive faces are oriented in opposite directions in different parts of the scopula: dorsally along the proximal most part of the scopula and ventrally on the distal part (e.g. Figs. 6a, c, 7a, c, d). 
Fig. 1 Scopula setae of theraphosids and barychelids (Strophaeus). a Hapalopus formosus, b Ami sp., c Vitalius sp., d Plesiopelma longisternale, e Holothele longipes, $\mathbf{f}$ Pterinochilus murinus, g Avicularia sp., h Strophaeus sp. All images leg I. $c h$ chemosensory setae
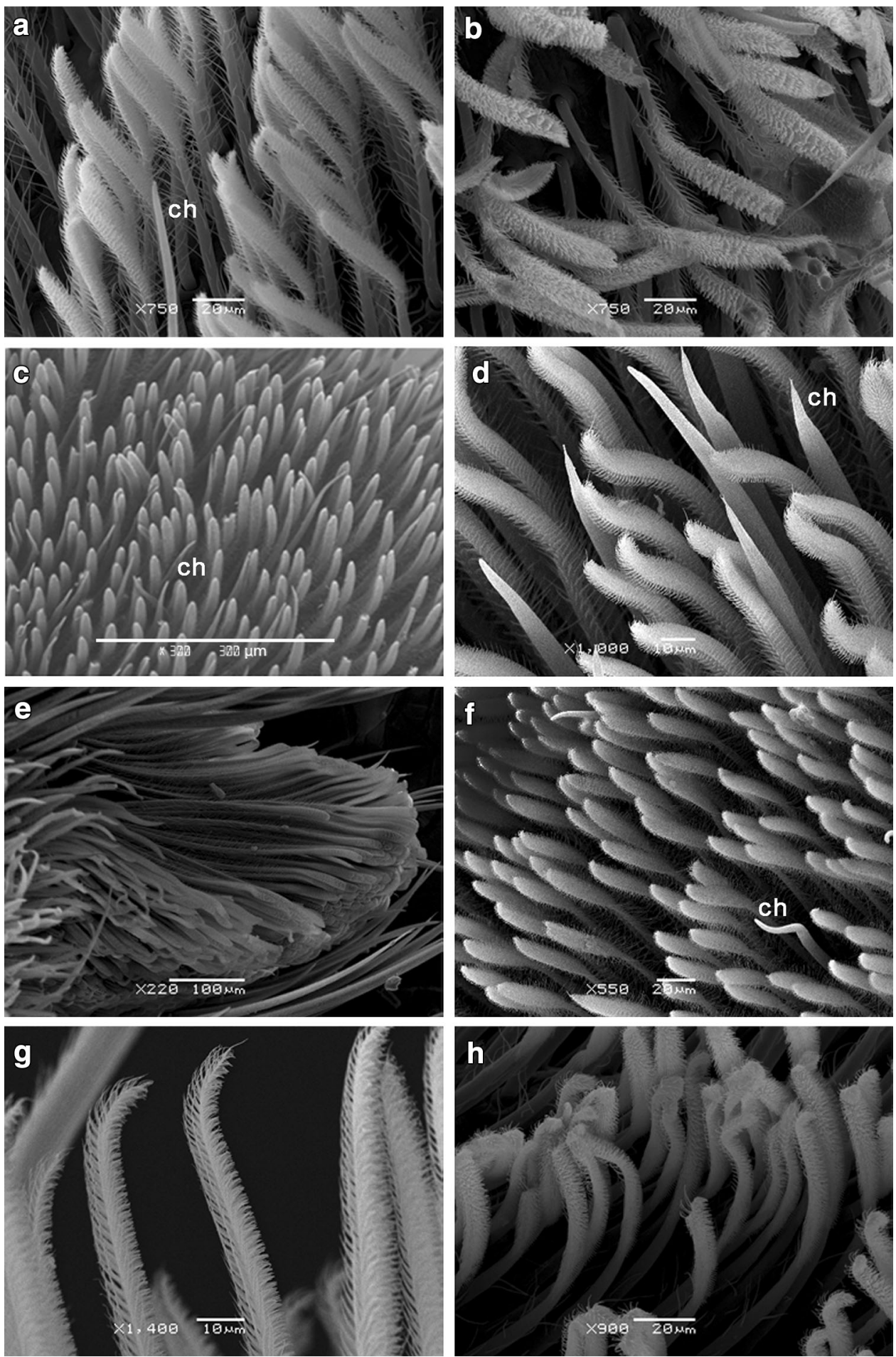

\section{Conical setae}

These conical setae are longer and thicker than lamellate and lance-shaped types (Fig. 9). Microtrichia are arranged in longitudinal rows, along the entire setae. Microtrichia on this setae are dense, shorter than in other types and filiform (not spatulated) (Fig. 9c, f). Conical setae are present in theraphosids and barychelids, mainly on the longitudinal median band of divided scopulae and few of them could be sparse among main setae. An approximately rhomboid field of these setae could also be found immediately under the claw tufts (e.g. Ami, Hapalopus). In Barychelidae we found that conical setae on distal and medial tarsi are strongly curved in the apical part, pointing proximally (Fig. $2 \mathrm{~g}$ ). 
Fig. 2 Tips of tarsi showing the orientation of adhesive setae. ad Hapalopus formosus (leg I), a lateral view, $\mathbf{b}$ distal ventral view, $\mathbf{c}$ detail of scopula setae (whites circles on $\mathbf{a}$ and $\mathbf{b}$ ), d detail of claw tuft setae (yellow circles on $\mathbf{a}$ and $\mathbf{b}$ ), e Holothele longipes (leg IV, ventral view), f Psalmopoeus ecclesiasticus (leg I, ventral view), g Strophaeus sp. (leg I, ventral view), h Strophaeus sp. (female palp, ventral view). Arrows with contour show the orientation of microtrichia (pointing to the tip). Arrow without contour points conical setae. ch chemosensory setae
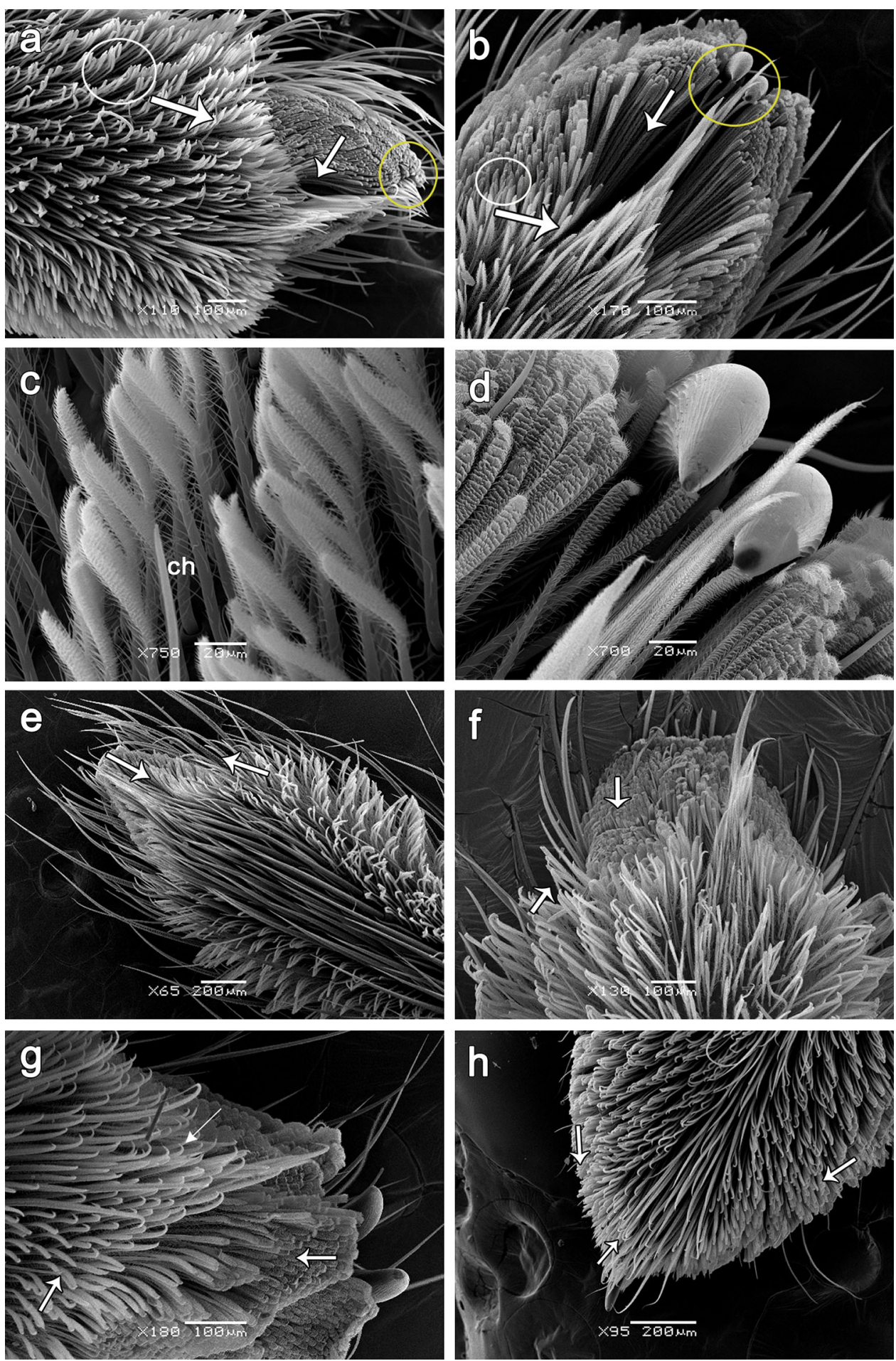

Non microtriched setae (chemosensory)

These setae are subconical, thick and with a domed apex, clearly differ from previous types in the absence of microtrichia and general morphology (Figs. 3e-h, g-h, 7f$\mathrm{h}, 8,10,11,12$ and 13).
Long, thin and striated chemosensory setae are widespread in males and females of mygalomorph families (e.g. Figs. 1a$\mathrm{d}, \mathrm{f}, 2 \mathrm{c}, 6 \mathrm{~b})$. Other chemosensory setae are exclusive of males; they are thick, obliquely striated and may show a subterminal overhanging cuticular hood (Fig. 13b), or a longitudinal indent (Fig. 13a, e, g), or an operculate like orifice (Fig. 13c, 
Fig. 3 Paratropidids. a-

d Melloina sp. female, tarsus I, a ventral view showing the claw tuft and absence of scopulae, b close-up of the median part of tarsus (ventral view), c close-up of the claw tuft (lateral view) (circle shows proximal setae, oriented to the axis of the leg), d close-up of a claw tuft lamellate setae showing the microtrichia on the ventral face (ventral view) $\mathbf{e}-\mathbf{h}$ Paratropis sp. male, e, f lateral view of tarsi showing pseudoscopula and absence of claw tuft, e tarsus I, f tarsus IV, $\mathbf{g}$ close-up of pseudoscopula $\mathbf{h}$ close-up of setae of pseudoscopula
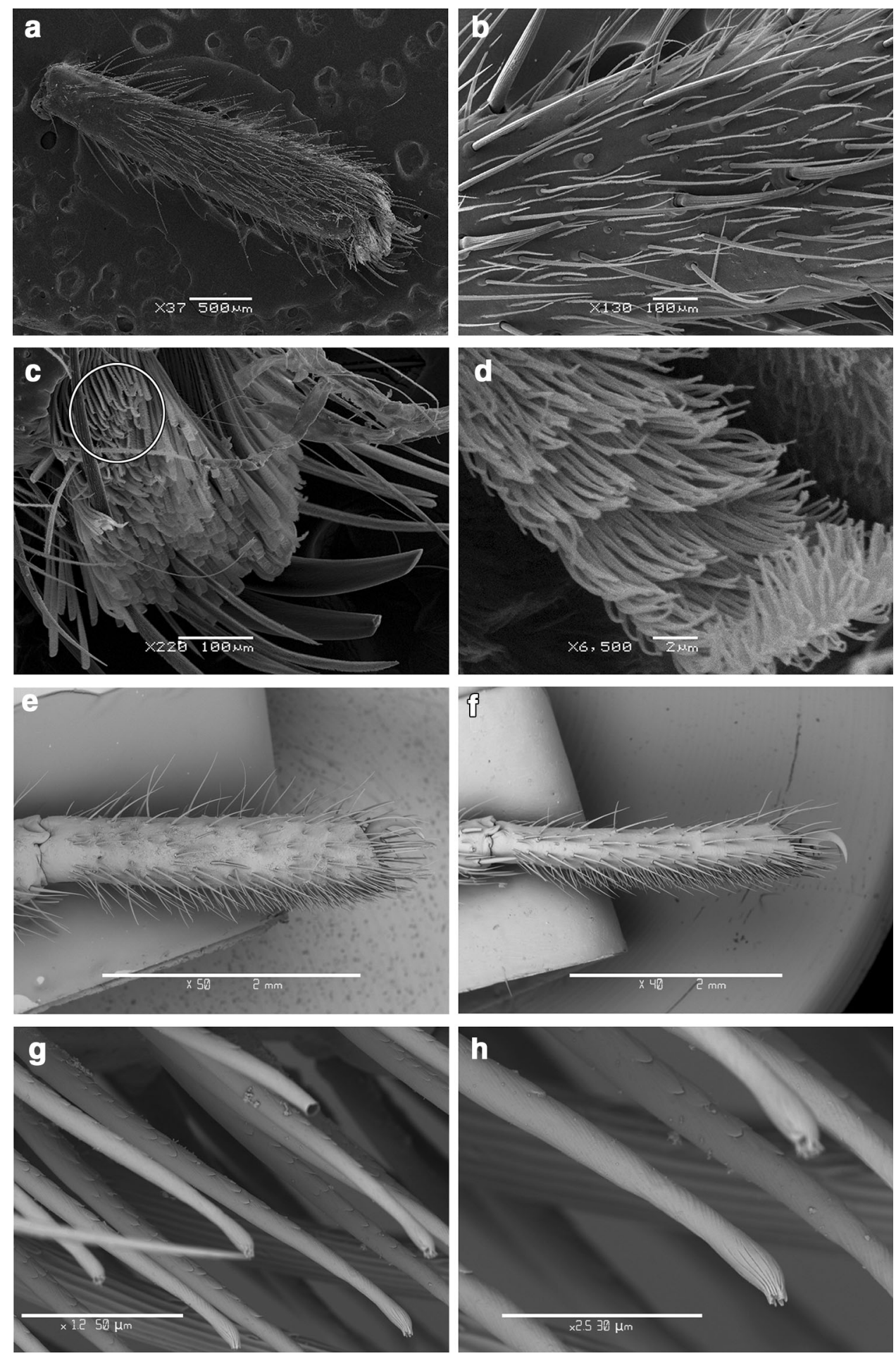

$\mathrm{d}, \mathrm{h})$. Some of these setae are apically extended by a filiform prolongation (Fig. 13e, f). Other chemosensory setae have a terminal orifice (Fig. 8d) that can be surrounded by a fringed edge (Fig. 3h). Male chemosensory setae can be sparse or distributed as densely as scopula setae (here nominated as pseudoscopula). These setae are present in all mygalomorph spiders, sometimes mixed with other tarsal setae. They are predominant, dense and resemble a scopula usually in non cursorial mygalomorphs as Actinopodidae (Figs. 12a-c, 13a), Antrodiaetidae (Figs. 11e-f, 13e), Atypidae, Ctenizidae (Figs. 11a, b, 13f), Idiopidae (Figs. 10a-d, 12d-f, 13b, c) (with the exception of Misgolas), Paratropis male (Fig. 3eh), Migidae (Figs. 11g, h, 13h), Euctenizidae males (Fig. 10e-h) and Hexathelidae (Figs. 11c-d, 13g). 
Fig. 4 Microtrichia on adhesive face of lamellate and lamellate-crested setae on Theraphosidae. a tip of a scopula lamellate crested setae of Plesiopelma longisternale (dorsal face), b close-up of microtrichia of $P$. longisternale (dorsal face), c scopula lamellate setae of Eupalaestrus weijenberghi showing microtrichia (dorsal face), d close-up of microtrichia of $E$. weijenberghi, e microtrichia of Grammostola anthracina (lateral view), $\mathbf{f}$ microtrichia of Pterinochilus murinus (lateral view), $\mathbf{g}$ microtrichia on lamellate setae of Psalmopoeus ecclesiasticus showing the arrangement in a band pattern, h microtrichia on lamellatecrested setae of Avicularia sp. showing the arrangement in a band pattern
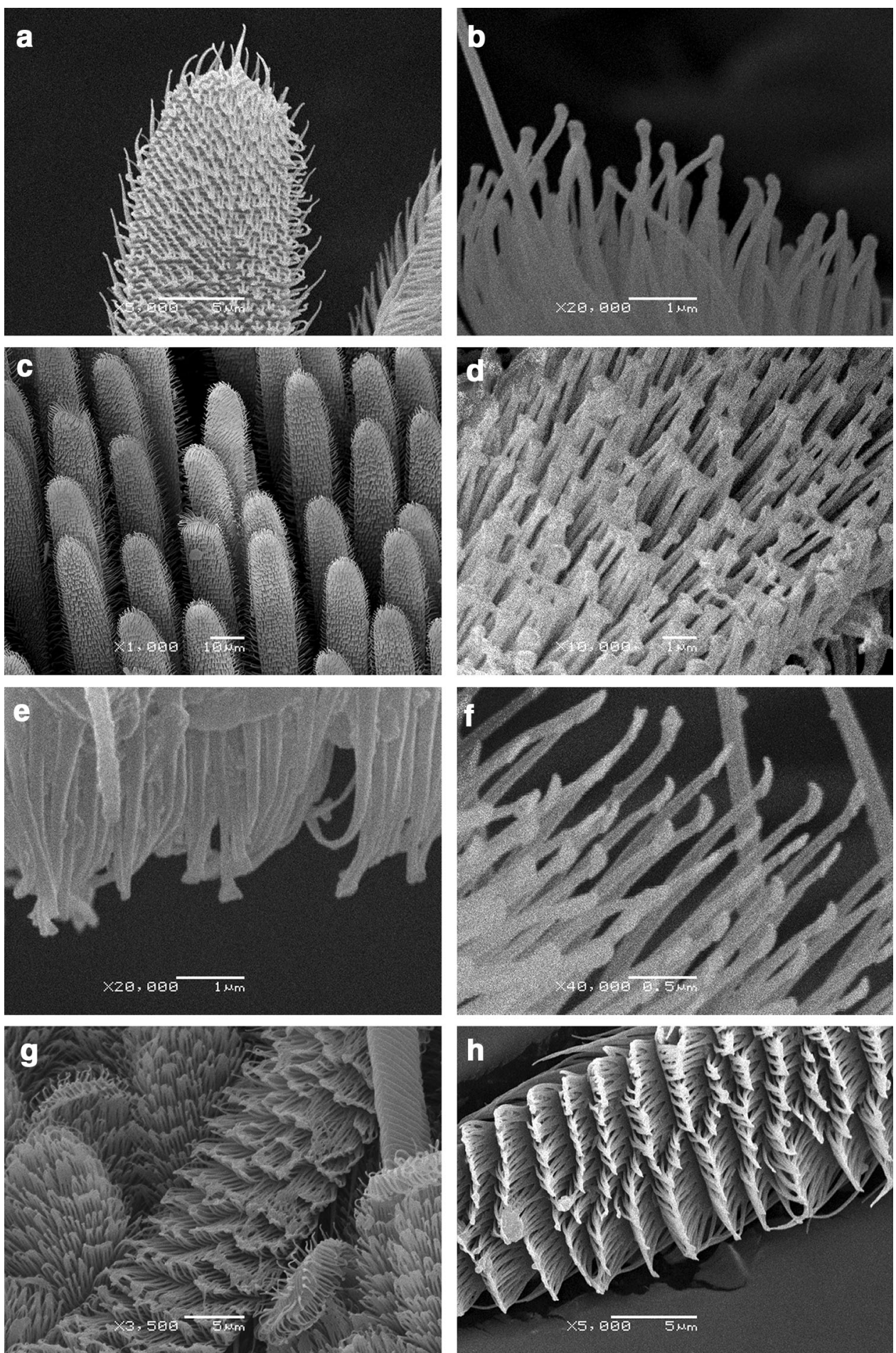

Arrangement of scopula and claw tufts in mygalomorph families

\section{Theraphosidae and Barychelidae}

Theraphosidae and Barychelidae comprise mostly cursorial and burrower spiders that predominantly live on the ground with the exception of some arboreal theraphosids (e.g. Aviculariinae) and some trap-door barychelids (e.g. Strophaeus). Both families present the co-occurrence of dense scopula and claw tufts. Scopula is present on ventral surface of tarsi and can be also present on part or whole metatarsi. We observed lamellate setae are predominant along scopula and claw tufts in most theraphosid and 
Fig. 5 Close-up of microtrichia on non-adhesive face of lamellate and lamellate-crested setae on theraphosids and barychelid (Strophaeus).

a Aphonopelma seemanni,

b Eupalaestrus weijenberghi,

c Plesiopelma longisternale,

d Grammostola anthracina,

e Avicularia sp., f Strophaeus

sp. (lateral view of the lamellate setae, above: non adhesive face, below adhesive face)
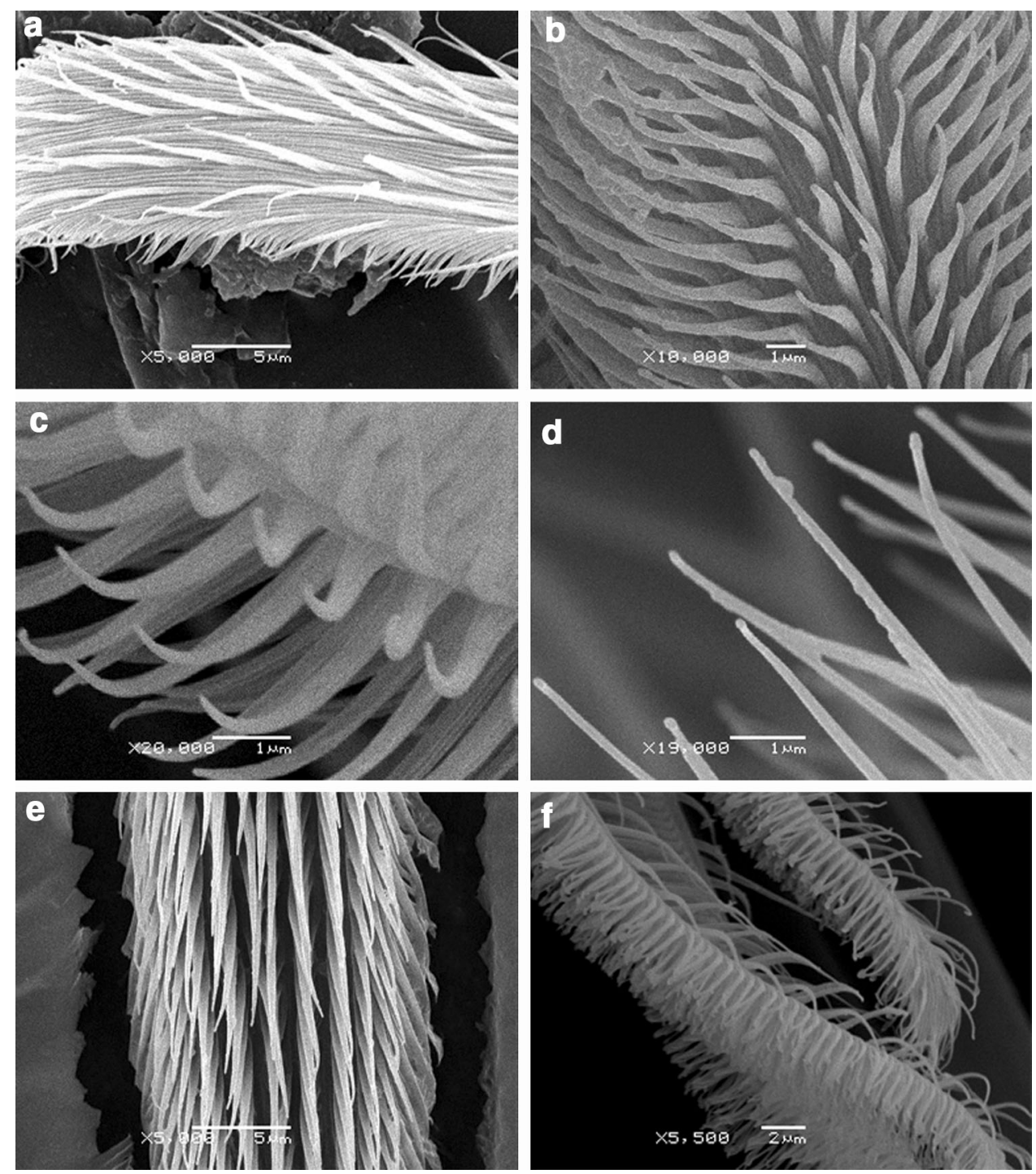

barychelid species while lamellate-crested was present in Plesiopelma longisternale, Homoeomma uruguayense and Avicularia sp. Conical setae were observed in the median band of the scopulae in the species with divided scopula and in some species also form a rhomboid arrangement below the claw tuft (transition zone of Lapinski et al. 2015).

In theraphosids with divided scopula, the median band of conical setae increases in width from anterior to posterior legs. Consequently, the lateral bands of lamellate adhesive setae are reduced (narrower) towards hind legs. Apart from this gradation we found another proximaldistal gradation of tarsal scopula division (Fig. 14). In several theraphosids with divided scopula the median band of conical setae is progressively widening toward the distal part of the tarsi from forelegs to hind legs (Fig. 14a-d). In theraphosids with transitional zone (e.g. Ami sp.,
Kankuamo marquezi Perafán et al. 2016) the anteriorposterior gradation is inverse, on leg I the field of conical setae is rhomboid and toward the hind legs this field is progressively widening toward the proximal part of tarsi (Fig. 14e-h). In the theraphosids with entire scopula the extension of the scopula relatively decreases from anterior to posterior legs, but no differences in setae density were observed.

Barychelid Strophaeus female present the scopula of palp, LI and LII asymmetrical (Fig. 15) with longer setae on prolateral side of tarsi and metatarsi.

\section{Melloina sp. (Paratropididae)}

Paratropidids are cursorial spiders found in leaf litter, and usually they lack claw tufts. Melloina is exceptionally the only mygalomorph genus studied here with claw-tuft and 
Fig. 6 Scopula, pseudoscopula and setae on cyrtaucheniids. af scopula and lance-shaped setae, a, b Bolostromus sp. female, a tarsus I, b scopula setae, close-up of (a), adhesive setae oriented dorsally, $\mathbf{c}$, d Kiama lachrymoides female, c tarsus I, b scopula setae, closeup of (c), adhesive setae oriented ventrally, e, f Fufius sp. female, e tarsus I, $\mathbf{f}$ detail of scopula. g, h Fufius sp. male, g pseudoscopula tarsus I,

h detail of pseudoscopula setae. Arrows show the orientation of microtrichia (pointing to the tip). ch chemosensory setae
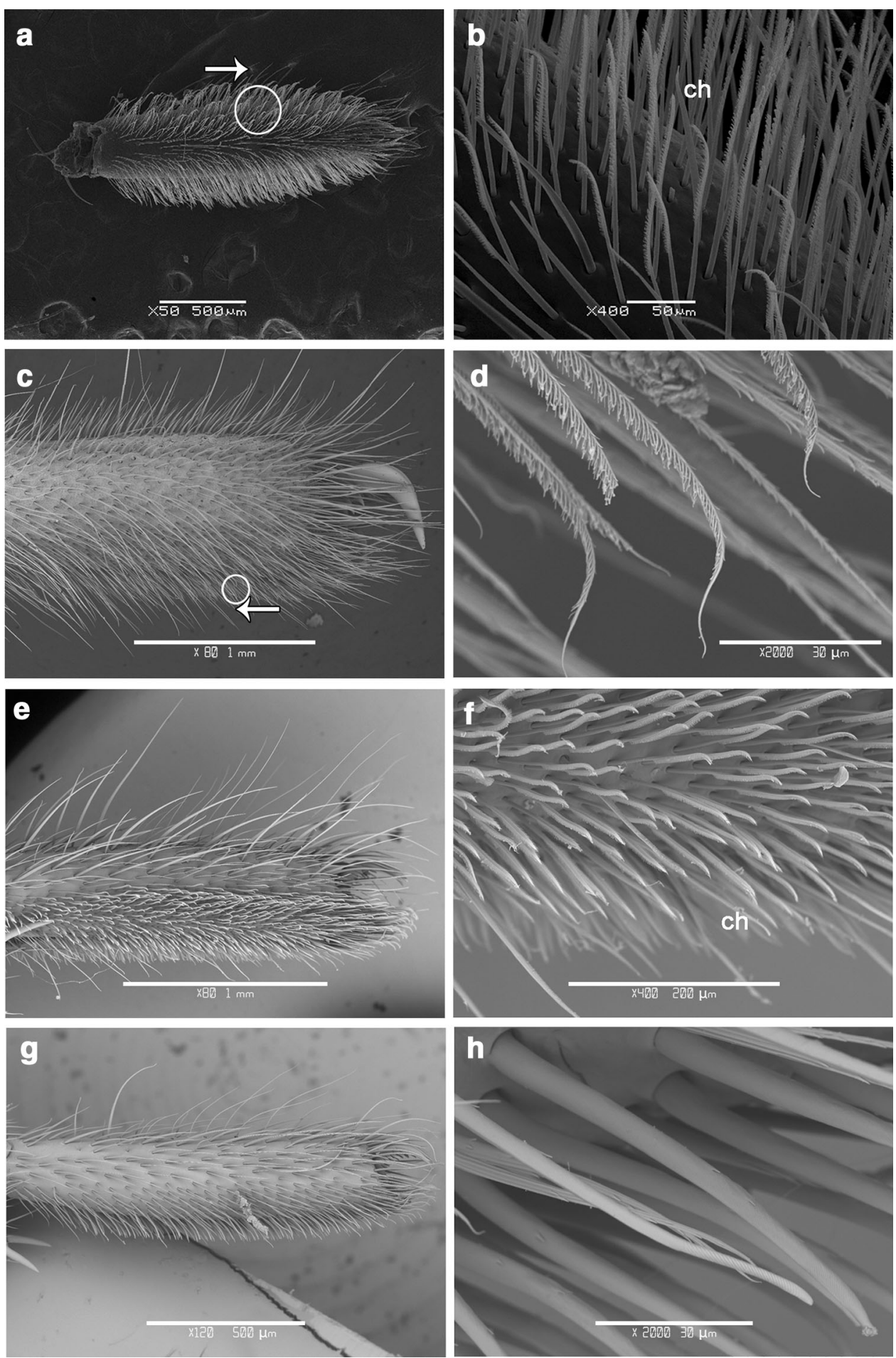

without scopula. Claw tufts are composed by lamellate setae. We observed in the proximal area of the claw tufts there are two lateral fields of adhesive setae with the adhesive face oriented toward the axis of the tarsus (Fig. 3c), while in the apical setae of claw tufts the microtrichia are oriented ventrally as usual in Theraphosidae and Barychelidae.
Cyrtaucheniidae, Diplurinae, Euctenizidae and Nemesiidae

Diplurids are sheet-web spiders, cyrtaucheniids are burrowers and nemesiids are a paraphyletic group including funnel weavers, burrowers and trap or flap-door species (Jocqué and Dippenaar-Schoeman 2007, Montes de Oca 
Fig. 7 Scopula, pseudoscopula and setae on nemesiids and diplurids. a-e lance-shaped setae, a, b Acanthogonatus tacuarensis, a distal part of scopula I, b scopula setae, close-up of (a), adhesive setae oriented ventrally. c-e Diplura sp., c distal part of scopula I, d medial part of scopula, e scopula setae. $\mathbf{f}-\mathbf{h}$ Linothele sp. male, $\mathbf{f}$ tarsus I,

g pseudoscopula setae, $\mathbf{h}$ detail of pseudoscopula setae. Arrows show the orientation of microtrichia (pointing to the tip)
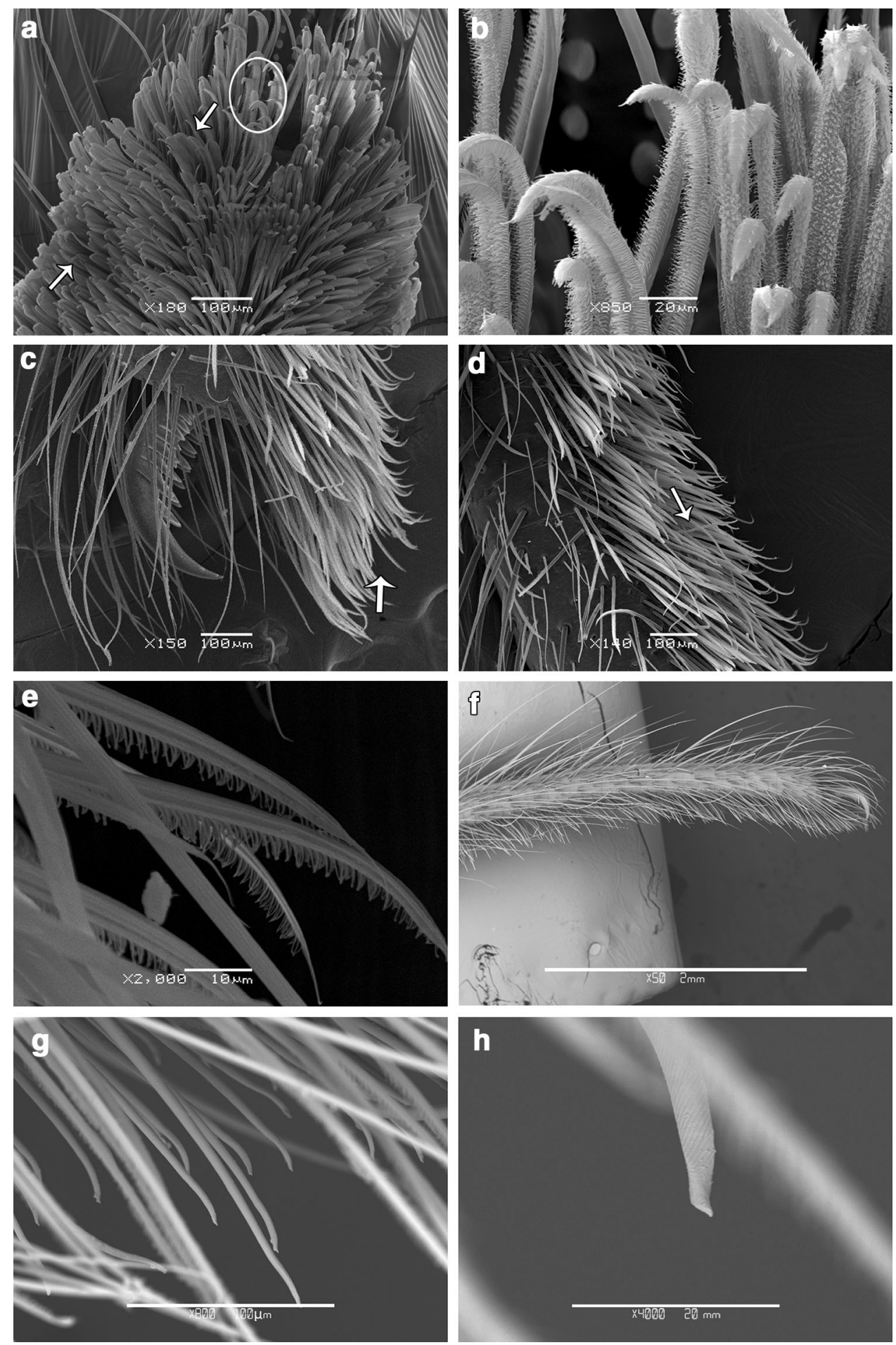

and Pérez-Miles 2013). These families present scopulae extended to the tip of tarsi but lack claw tufts. In some euctenizids, nemesiids and diplurids females, lance-shaped setae are mixed with chemosensory setae, with no predominance of any of them (Figs. 6a-f, 7a-e). These structures show an anterior-posterior gradation, usually decreasing in density to the hind legs. In cyrtauchenids and euctenizids we observed sexual dimorphism expressed by adhesive scopula in females and pseudoscopula in males. In the non-trapdoor cyrthaucheniid females Bolostromus the scopula of posterior legs are more dense in the periphery of ventral tarsus than in the center, where the setae are more sparse. Euctenizids are burrowers or thin wafer-lid trapdoor; most females bear scopula and males 
Fig. 8 Xenonemesia otti male. a tarsus I, $\mathbf{b}$ detail of ventral view showing mixed adhesive setae and chemosensory setae, c detail of adhesive setae, d detail of chemosensory setae. Black arrows indicate adhesive setae and white arrow indicate chemosensory setae
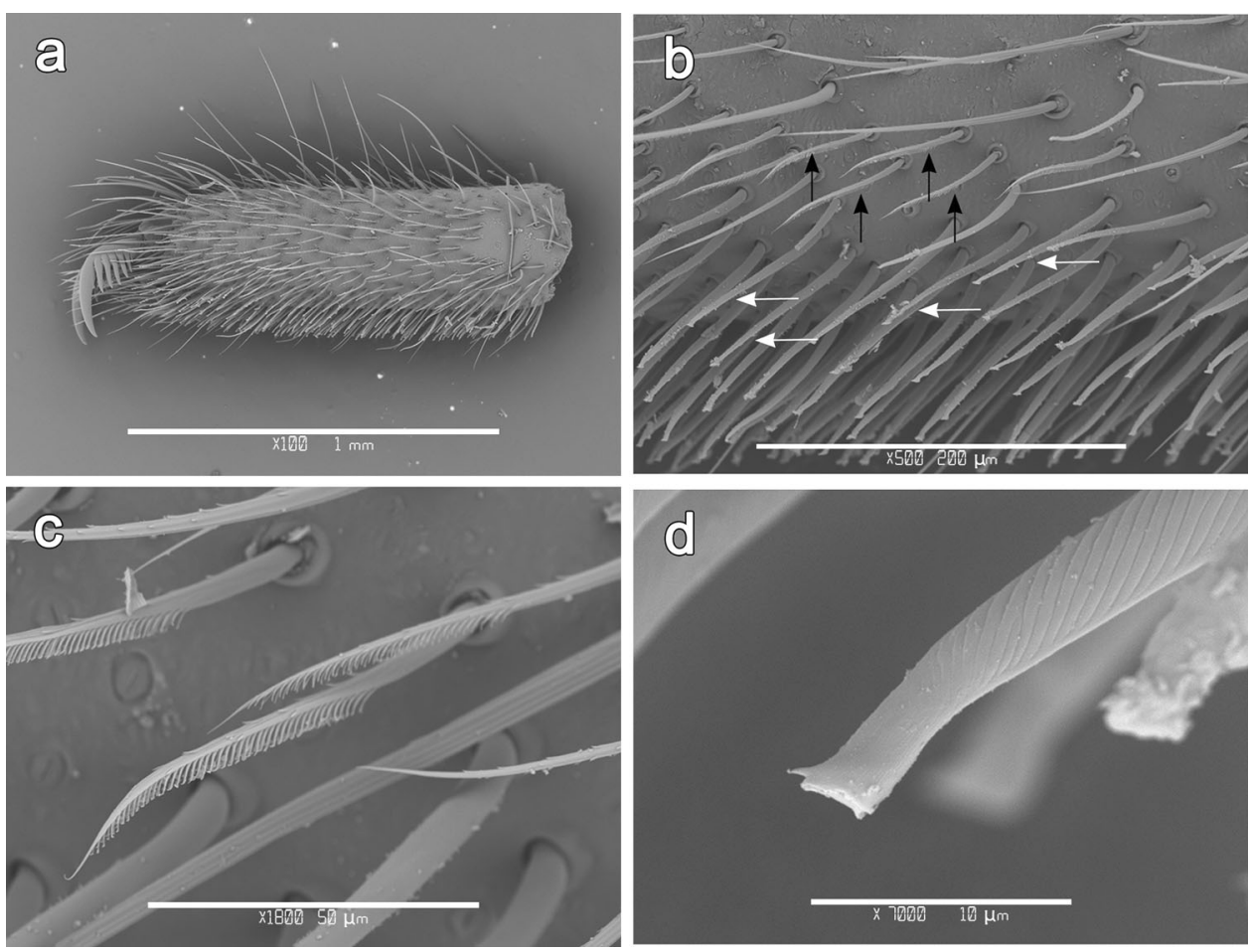

present pseudoscopula. Most diplurid genera in Euagrinae and Ischnothelinae lack scopula and males present pseudoscopula; conversely Diplurinae are the exception and present scopula on all tarsi (Linothele, Diplura, Trechona). In this group the scopula decreases in extension and/or also in density to the hind legs. Other non Diplurinae show sexual dimorphism: males have pseudoscopula but females lack scopula and pseudoscopula (e.g. Australothele, Stenygrocercus, Cethegus, Caledothele, Namirea, Ischnothele).

Trapdoor families, Paratropis (Paratropididae), Atypoidea and Hexathelidae

Male of Actinopodidae, Antrodiaetidae, Atypidae, some Cyrtaucheniidae, Ctenizidae, Idiopidae (with the exception of Misgolas), many Hexathelidae, the paratropidid genus Paratropis and the migid genus Migas present pseudoscopula. The pseudoscopula comprises non microtriched chemosensory setae but with the surface ornamented (Figs. 3e-h, 6h, 10, 11 and 12). The pseudoscopula shows a remarkable sexual dimorphism, being only present in males. With the exception of Paratropis, the pseudoscopula shows an anterior-posterior gradation opposite to that observed in the adhesive scopula, increasing in extension and density to hindlegs. The migid representative Calathotarsus simoni Schiapelli and Gerschman (1975) and hexathelid Scotinoecus cinereopilosus (Simon 1889) did not present scopula or pseudoscopula, but present sparse chemosensory setae. Some morphological variations of chemosensory setae apex are characteristic of some families (see setae description and Fig. 13).

\section{Phylogeny of setal pads}

In a first approach, we mapped the microtriched, adhesive setae on the phylogeny of Bond et al. (2012) (Fig. 16a). Adhesive scopulae were acquired in the Crassitarsae, in the Euctenizidae and in some idiopids (Misgolas, Euoplos and Aganippe). When we compared the presence of adhesive scopula with the lifestyle condition using Ridley's method (Ridley 1983) we found a significant association between the adhesive setae and cursorial/burrower taxa $(P=0.047)$, despite of their exceptional presence in some trapdoors and Diplurinae (Fig. 16a, b).

We also mapped the scopula, pseudoscopula or mixed condition: scopula/pseudoscopula (Fig. 17). The pseudoscopula is widespread among mygalomorph males, with reversions in Theraphosoidina into adhesive scopula and unknown state in some groups. In most nemesiids, mixed adhesive and chemosensory setae was the more common state in males and females, as well as some males of Barychelidae and Theraphosidae. Mygalomorph females lack pseudoscopula, but have chemosensory setae mixed with adhesive setae as explained for nemesiids or fewer and sparse. Females of Theraphosoidina, nemesiids Ixamatus and Kiama and cyrtaucheniids have adhesive scopula and have sparse chemosensory setae. Female 
Fig. 9 Conical setae. a-

c Hapalopus formosus, a distal part of leg IV, b claw tuft of leg I, c conical setae of scopula. d Bolostromus sp., distal part of leg I. e, f Holothele longipes, e distal part of scopula leg I, f conical setae scopula leg IV. g, h Strophaeus sp., g leg IV, h scopula. Arrows point the conical setae
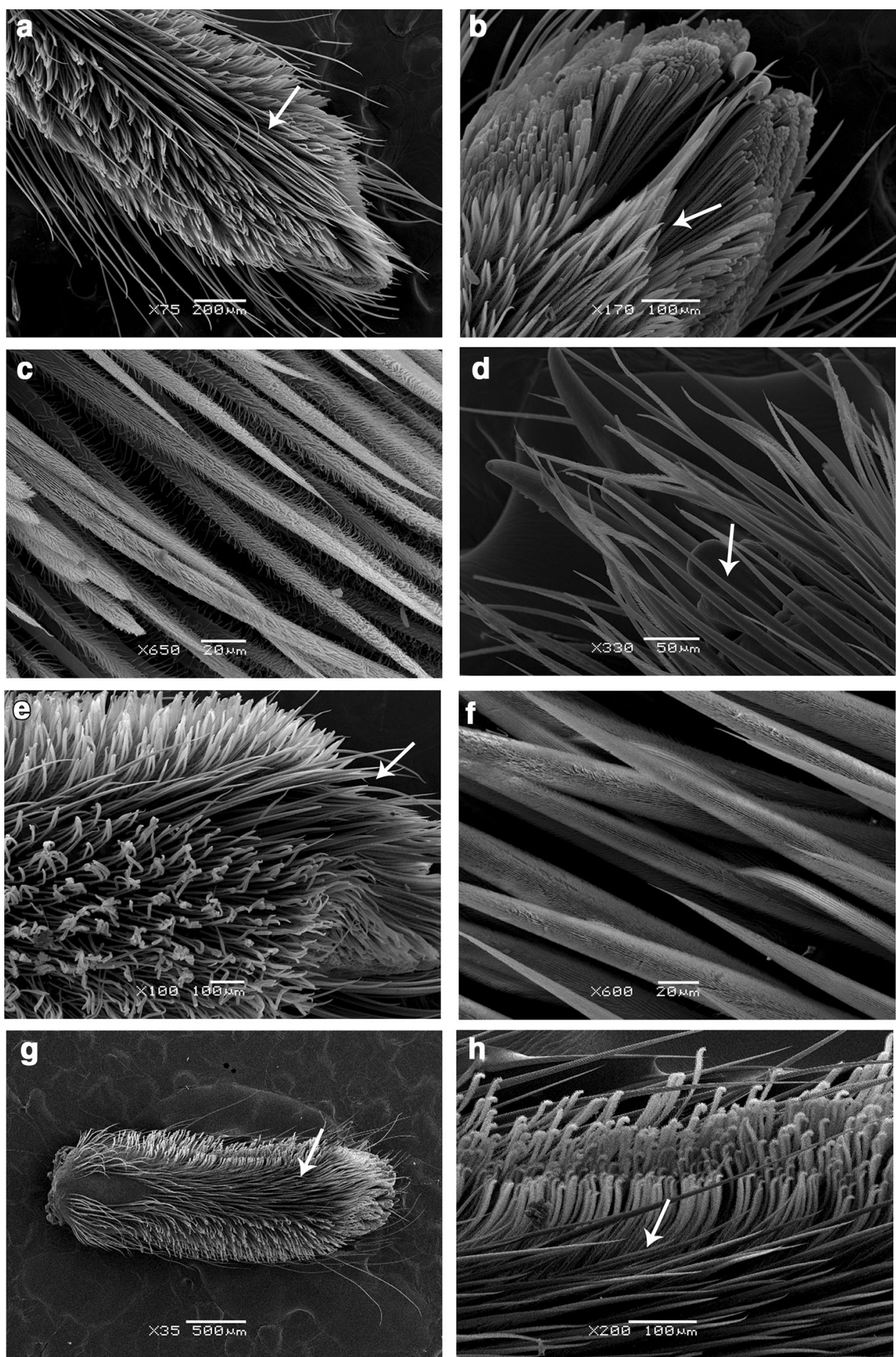

chemosensory setae are slender and more acuminate than those of male pseudoscopula (e.g. Fig. 6b, f).

We studied the anterior-posterior gradation of scopula and pseudoscopula in males and we found that adhesive scopula usually increased towards anterior legs, while pseudoscopula increase to posterior legs in some groups (e.g. most Atypoidea, Hexathelidae, Actinopodidae, some migids and some idiopids).

Claw tufts were acquired only once in the clade Barychelidae + Theraphosidae. Melloina (Paratropididae) 
Fig. 10 Idiopids and euctenizds. a, b Aganippe sp. male a tarsus I, $\mathbf{b}$ details of pseudoscopula. c, d Euoplos variabilis male a tarsus I, b details of pseudoscopula. e, f Aptostichus simus male e tarsus I, $\mathbf{f}$ detail of chemosensory setae. $\mathbf{g}$ h Myrmekiaphila sp. male g tarsus I, arrow indicates adhesive setae on the distal tarsus $\mathbf{h}$ detail of chemosensory setae
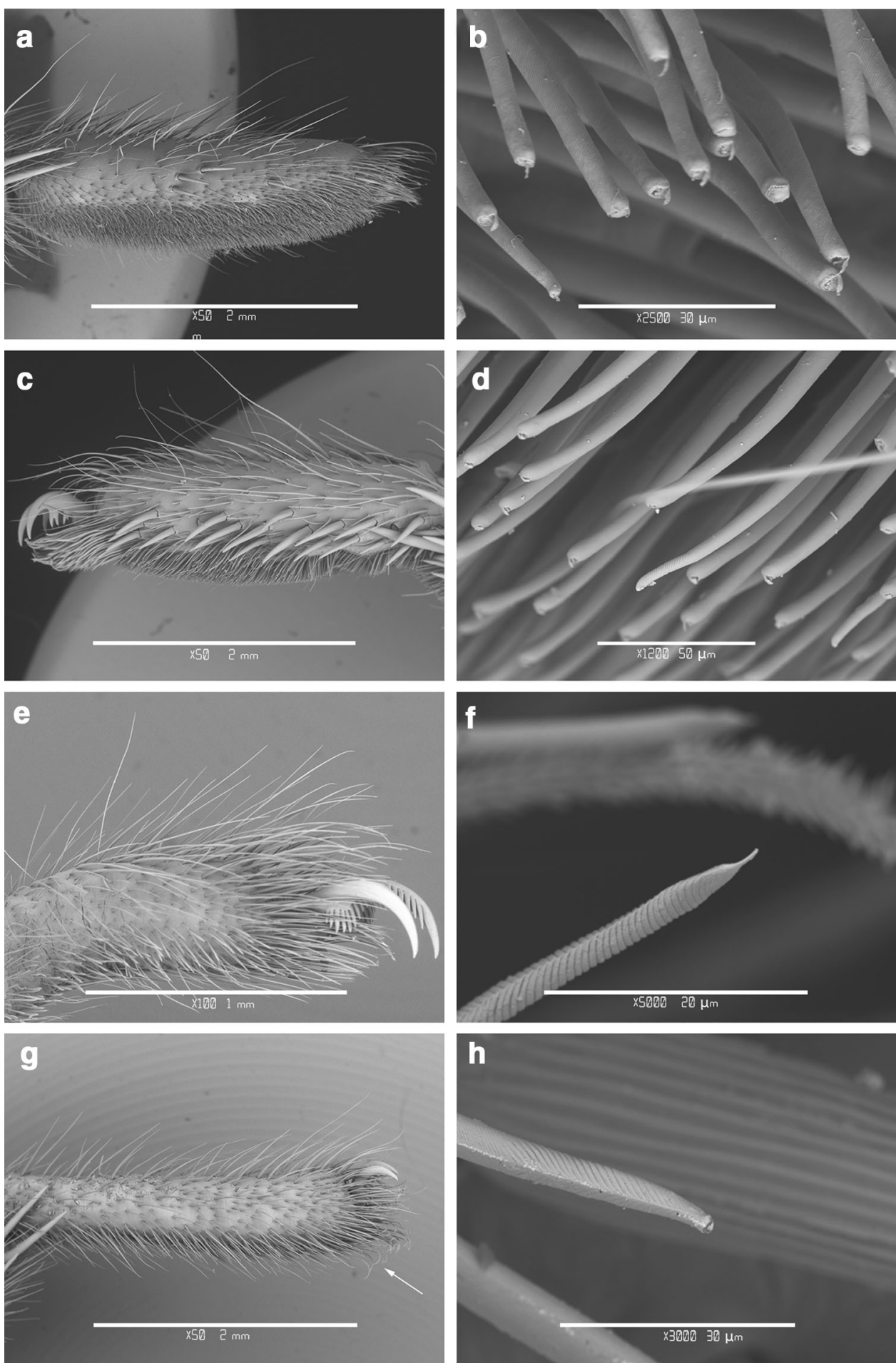

present claw tufts but was not included in the cladogram of Bond et al. (2012).

In general, the absence of adhesive scopula in females correspond to trap-door and weaver mygalomorphs (with the exception of Euctenizidae and some idiopids) while the presence of adhesive scopula or claw tufts was associated with open burrowers spiders (Fig. 16).

\section{Discussion}

\section{Adhesive setae: morphology and functions}

Comparing mygalomorph adhesive setae with those found in araneomorphs, most types with the exception of non microtriched, are similar to those indicated by Wolff et al. 
Fig. 11 Pseudoscopula. a,

b Ummidia sp. male

(Ctenizidae) a tarsus I, b details of pseudosopula. c,

d Hadronyche sp. male

(Hexathelidae) c tarsus I,

b details of pseudosopula. e,

f Antrodiaetus sp. male

(Antrodiaethidae) e tarsus IV,

$\mathbf{f}$ details of scopula. $\mathbf{g}, \mathbf{h}$ Migas nitens (Migidae) $\mathbf{g}$ tarsus IV,

h detail of scopula
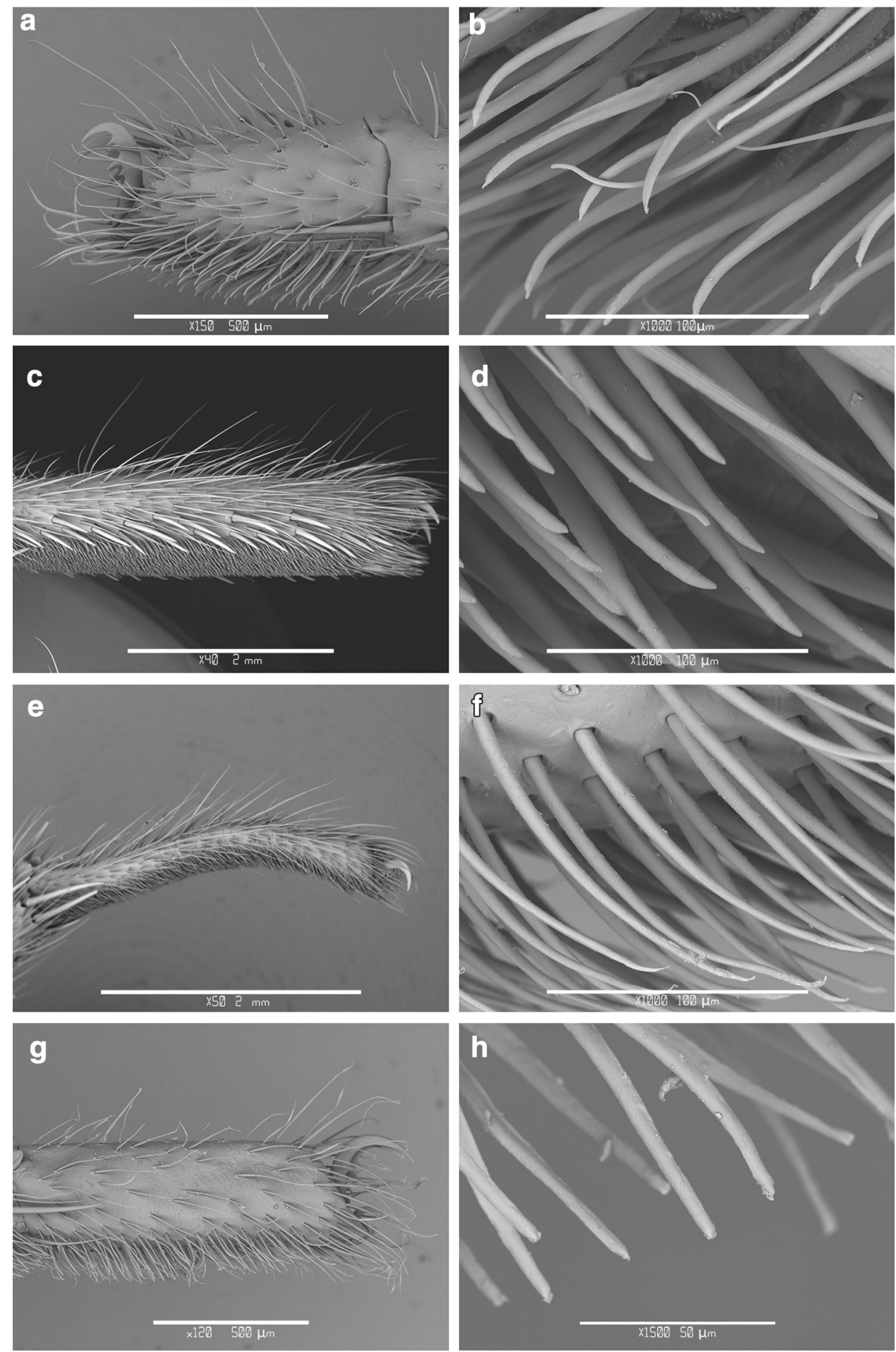

(2013) and Lapinski et al. (2015) (Table 2). With the exception of conical and non-microtriched setae, the other setae types studied are interpreted as adhesive, because of the presence of spatulated microtrichia, which was considered as an indicator of adhesive properties in spiders (Wolff and Gorb 2012a; Ramírez 2014), including
Mygalomorphae (Pérez-Miles 1994). Apical region of lamellate setae is curved and seems to be as flexible as in araneomorphs (Wolff and Gorb 2016), facilitating movements for the contact of microtrichia.

Conical setae with no spatulate microtrichia seem to be more related to traction or propulsion during locomotion as 
Fig. 12 Actinopodidae and Idiopidae. a-c Actinopus sp. male a tarsus IV, $\mathbf{b}$ detail of pseudoscopula setae, tarsus IV c detail of non-microtriched setae (leg iv). d-f Idiops clarus d tarsus IV, e tarsus II distal part, $\mathbf{f}$ detail of pseudoscopula setae
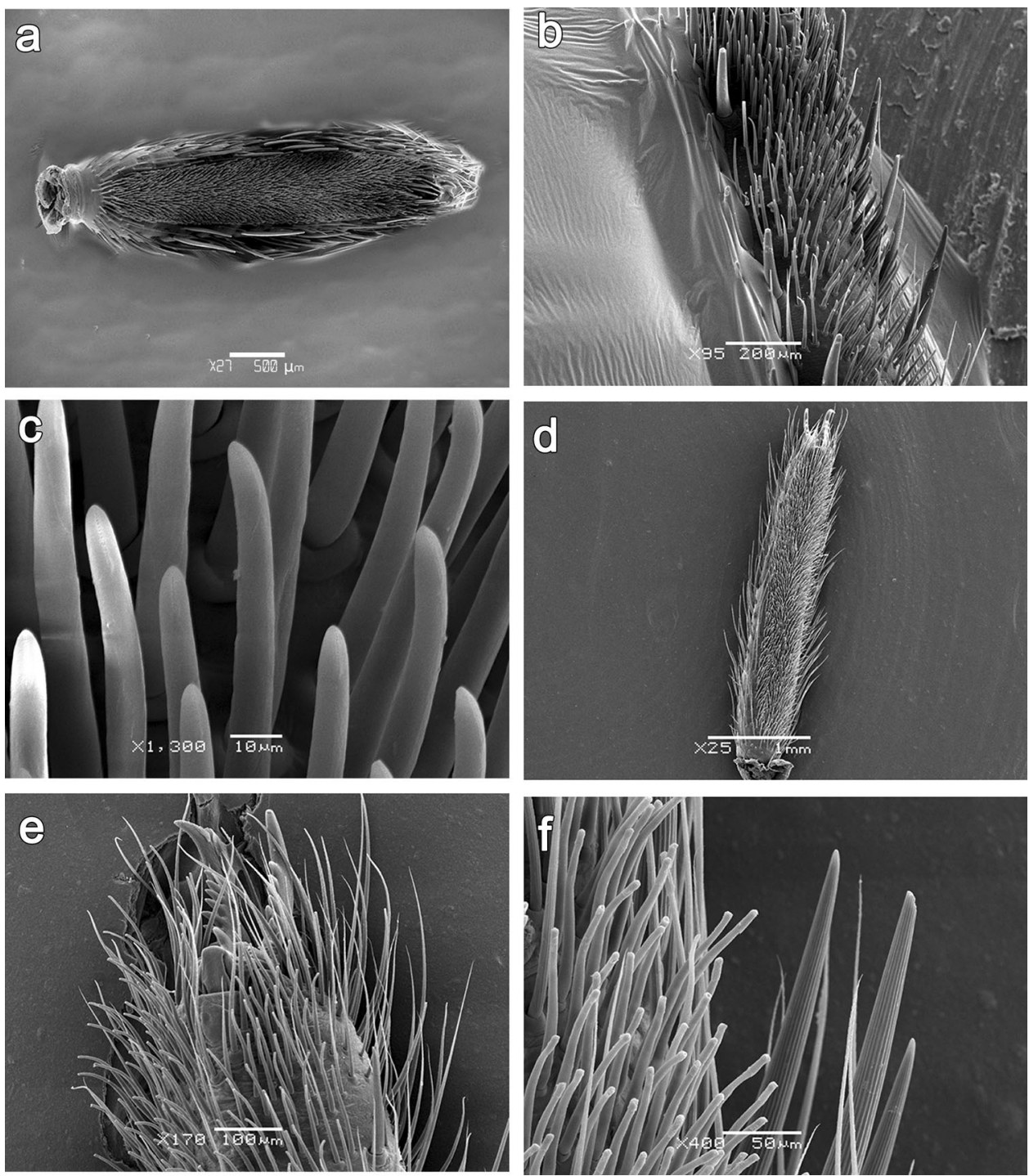

suggested by Rovner (1978) for lycosids, Pérez-Miles (1994) for theraphosids and Wolff et al. (2013) called them as frictional setae.

We found that the orientation of the anisotropic adhesive setae differs between proximal tarsus in comparison with the tip of the tarsus (apical scopula or claw tuft), due to different anisotropy in the location of the microtrichia, similar to what has been reported for large araneomorph hunting spiders (Wolff and Gorb 2013). This specific arrangement has been hypothesized to play an important role for friction control. Considering the morphology, it is expected that distal setae produce adhesion when the leg pulls while proximal setae produce adhesion when the leg pushes. This hypothetical mechanism is congruent with the observations of Pérez-Miles et al. (2015) but differs from results by Niederegger and Gorb (2006) who found higher adhesion on scopula when the leg pushes in the theraphosid Aphonopelma seemanni.
Rovner (1978), Foelix et al. (1984), Pekar et al. (2011), Wolff et al. (2013) and Eggs et al. (2015) proposed the participation of scopulae in prey manipulation in Araneomorphae but some characteristics we found in Mygalomorphae at first question this function. This is only applicable to apical scopula or claw tufts considering that the adhesive faces of most part of scopula setae are oriented dorsally (distally) facilitating pushing adhesion. Pushing adhesion mechanism enters in conflict with the use of adhesive setae for prey capture, at least in first steps of prey attraction, because for prey attraction the adhesion must be produced when the forelegs pull the prey toward the chelicerae. However, once capture is advanced and the spider is above the prey and with legs at the sides and below, pushing adhesion may be effective.

Other interpretation is related with the full control of prey by predator due to the mechanics of moveable setae. Eggs et al. (2015) proposed that erectile scopular setae 
Fig. 13 Close-up of

chemosensory setae present on pseudoscopula. a Actinopus sp. b Idiops clarus, c Euoplos variabilis, d Aganippe sp., e Antrodiaetus sp., f Ummidia sp., g Hadronyche sp., h Migas nitens
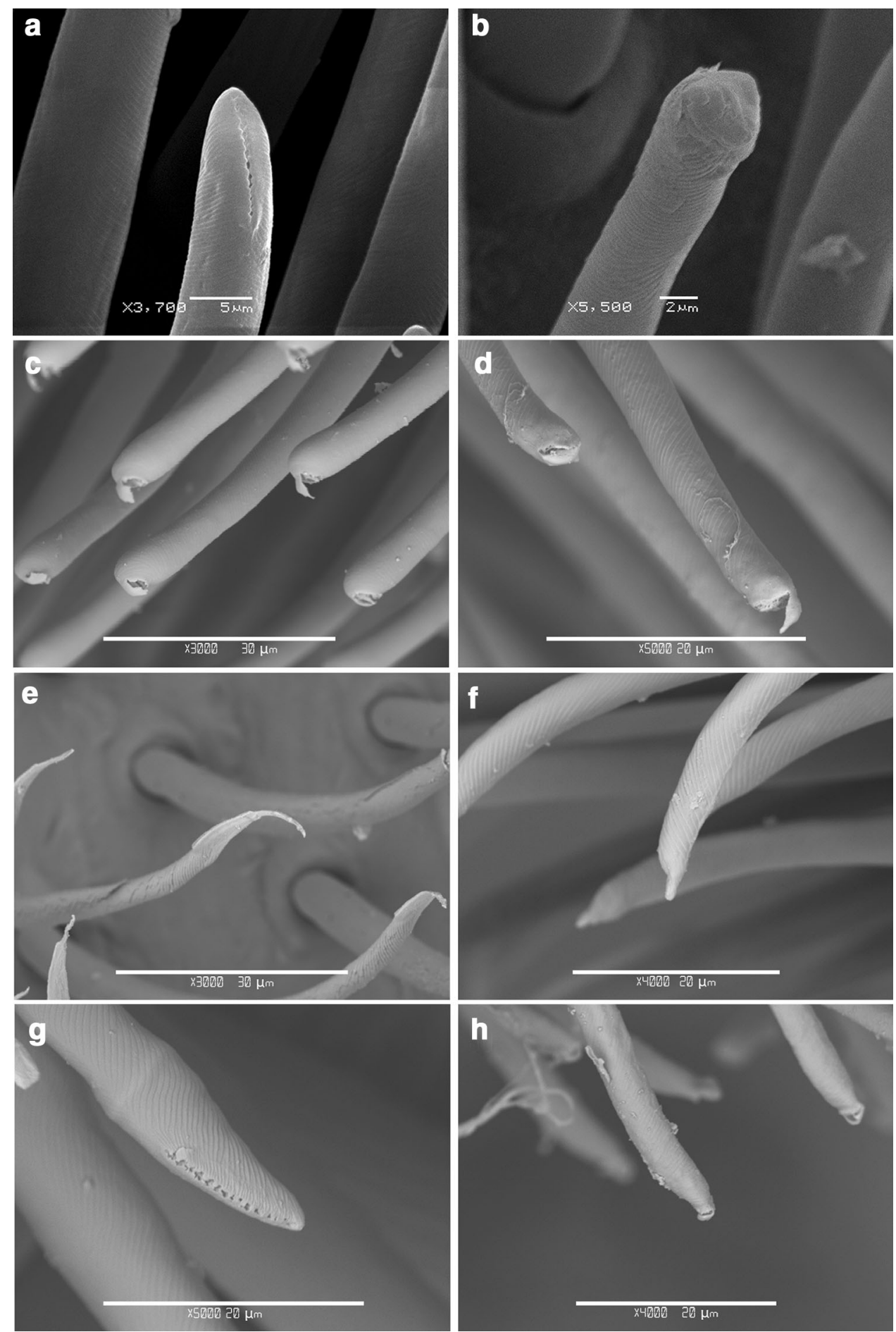

could change of orientation during attack, which could be an alternative explanation for adhesion during prey capture. This is also possible in mygalomorphs since claw tufts setae are moveable (Dunlop 1994; Labarque et al. 2017). Additionally, Wolff and Gorb (2012a) stressed the importance for the predator to release the prey if it turns out to be hazardous, which should be facilitated by the control of adhesion.
Pulling adhesion is expected in claw tufts or the extreme of tarsal scopula, so these features could be involved in both prey capture and adhesion for locomotion. When the spider climbs vertically upward, the adhesion may be produced by apical adhesive setae of forelegs pulling and proximal scopula of hind legs pushing (Pérez-Miles et al. 2015) with a similar dynamics as proposed by Wolff and Gorb (2013) and Wohlfart et al. (2014), for Cupiennius 

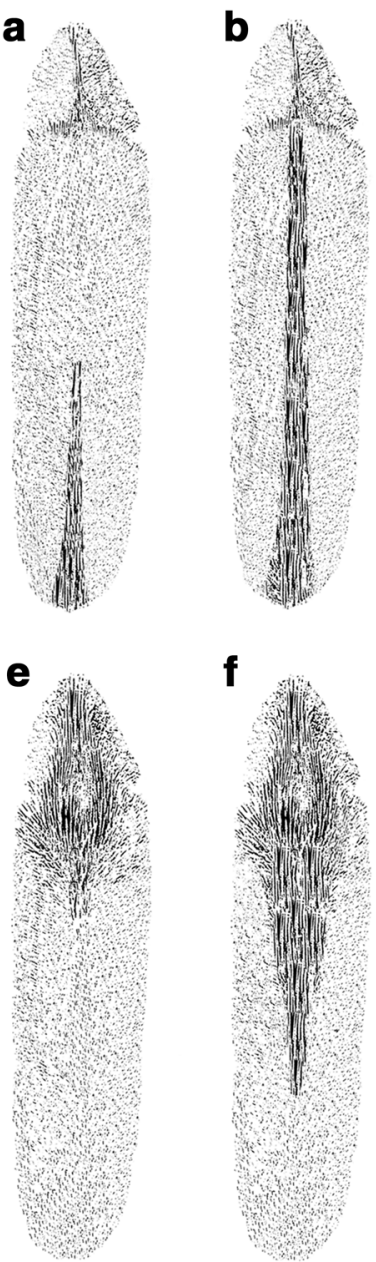

f

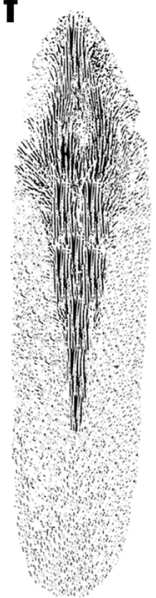

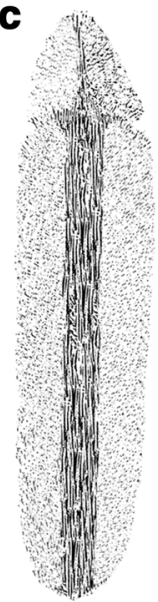

d

9

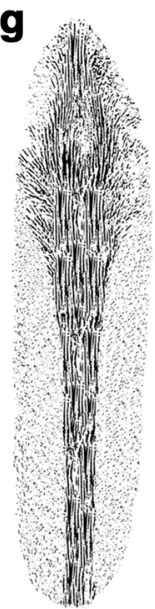

h
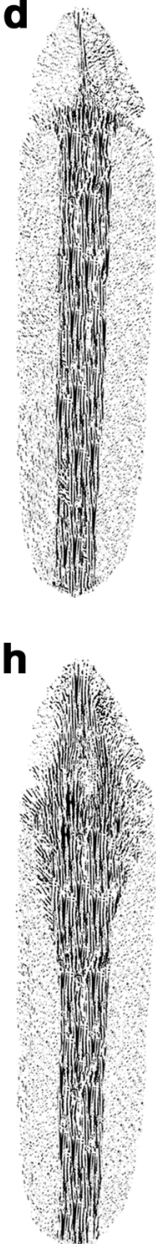

Fig. 14 Schematic representation of scopula division: proximal/distal and anterior (left)-posterior (right) gradation in a-d Plesiopelma longisternale and Homoeomma uruguayense, $\mathbf{e}-\mathbf{h}$ Ami spp. and Kankuamo marquezi

salei (Keyserling 1877). Inversely, when the locomotion is oriented downward, anterior scopulae push and posterior claw tufts (or distal scopulae) pull. Resting position in arboreal theraphosids is usually head down (Fig. 18). This behavior could explain the anterior-posterior gradation of scopula indicated by Raven (1985) who observed an increasing development of such features in anterior direction. Obviously front legs are mainly involved in prey capture, as the first explanation for anterior-posterior gradations (Wolff and Gorb 2012a; Eggs et al. 2015). Perhaps mainly tarsal tip is involved in initial stages of prey capture while both: tip and most part of tarsi are involved in climbing and late stages of prey capture.

Wolff et al. (2013) found a close association between the adhesive setae and the free hunter lifestyle in spiders. They suggest that scopulae evolved as a substitute for silk in controlling prey and that the claw tufts are, in most cases, a secondary development. In general terms our

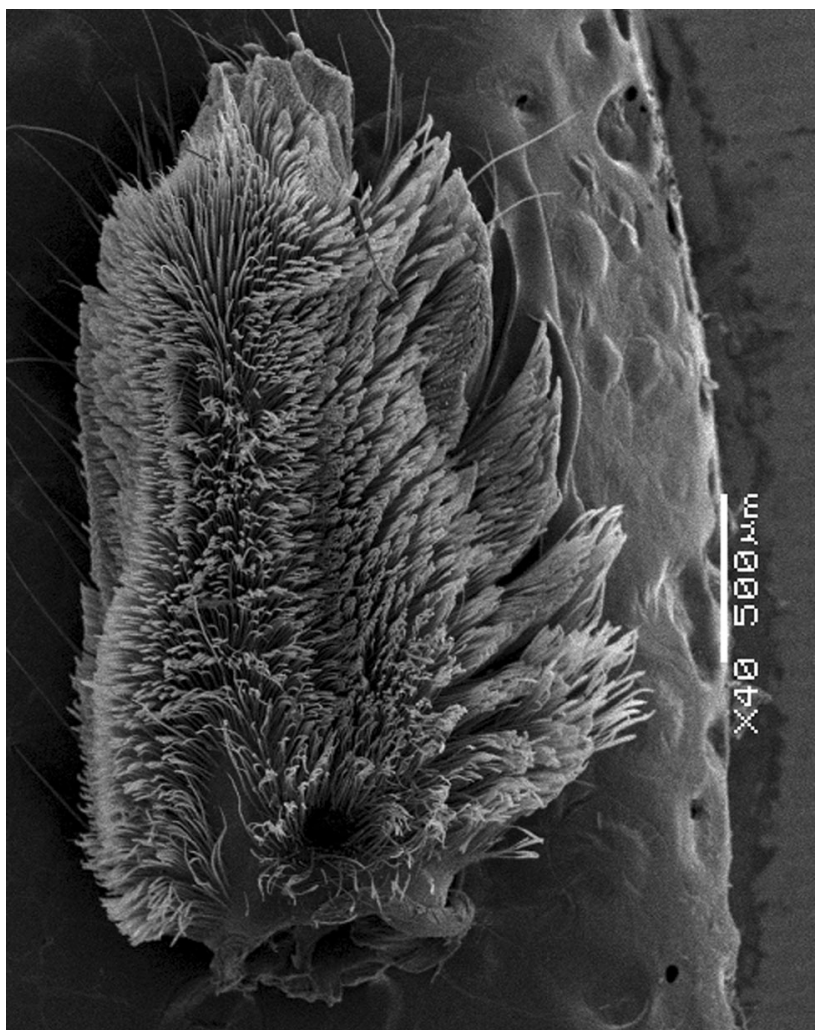

Fig. 15 Right tarsus of leg I of Strophaeus sp., ventral view showing the asymmetrical scopula (longer on prolateral side)

results agree with these authors. Among the Mygalomorphae Wolff et al. (2013) reported the adhesive setae in Barychelidae, Cyrtaucheniidae, Idiopidae, Paratropididae, Nemesiidae and Theraphosidae. We find adhesive setae in females of the idiopids Misgolas, Euoplos e Aganippe, diplurids Diplura, Trechona and Linothele, some euctenizids, and also nemesiids; some of them use a sheet-web for prey capture or inhabit wafer-lid trapdoor; therefore, these groups may be exceptions to Wolff et al. (2013) hypothesis.

Leg morphology and mainly the presence of adhesive setae may be key to understand spider ecology. Several authors recently suggested that wandering spiders living in higher strata have more developed adhesive pads than those living mainly on the ground (Jocqué and Alderweireldt 2005; Wolff and Gorb 2012a, 2015; Wolff et al. 2013; Lapinski et al. 2015). These studies focused mainly on Araneomorphae. The presence of adhesive setae strongly suggests the importance of adhesive setae in locomotion and mainly to climb on inclined or vertical surfaces. Mygalomorphs walk on horizontal surfaces using their tarsal tips, but when climbing on vertical surfaces a close contact is observed between most part of tarsi which push on the surface (Pérez-Miles et al. 2015). Arboreal species of Mygalomorphae (e.g. theraphosid Aviculariinae) 


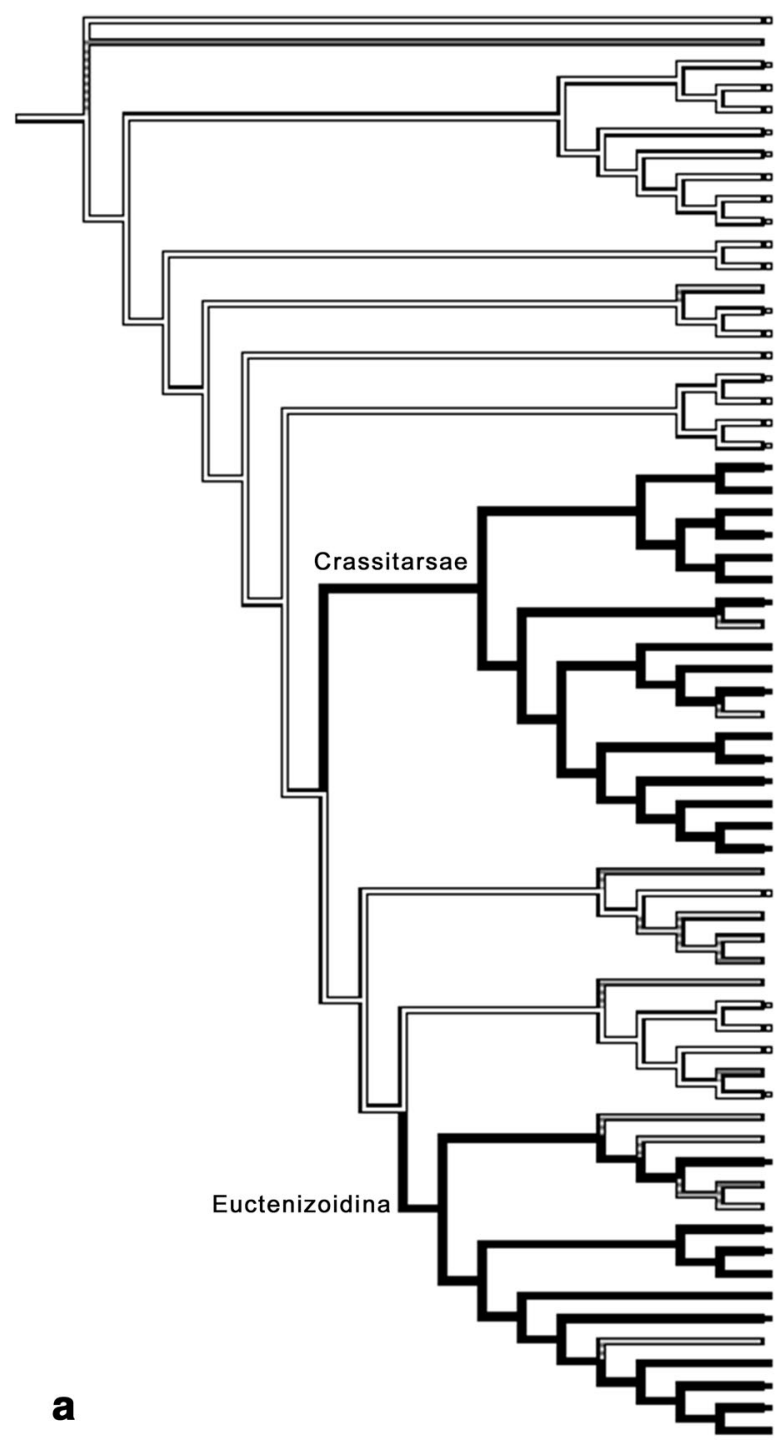

Liphistivs

Hypochius

Megahexura

Atypus

Sphodros

Hexura

Antrodiaetus 1

Antrodiaetus

Antrodiaetus 2

Bymainiella

Praembolides

Euagrus

Allothele

Australothele
Paratropis

Paratropis

Actinopus

Misulen

Hacronyche

Ancylotrypa

Ancylotypa

Acanthoscurria

Aphonopelma

Ozicrypta

Synothele

Cyrtauchenius

Calsogat

Morostigmata

lxamatus

Kiama

Aname

Chenistonis

Fufus

Acanthogonatus

Acanthogon atus

Moggridgea2

Migas

Heteromigas

Heteromigas
Mogridgea1

Poeciomigas

Postiomgas
Stasimoous

Stasimopus
Conothele

Conothele

Uydocosmia

Bothriocyrtum

Hebestatis

Segregara

Anidiops

Misgolas

Homogona

Mymmekiaphls

Apomastus

Aptostichus

Promyrmekiaghila

Neoapachella

MossLanding

Entychides2

Entychides

Eucteniza1

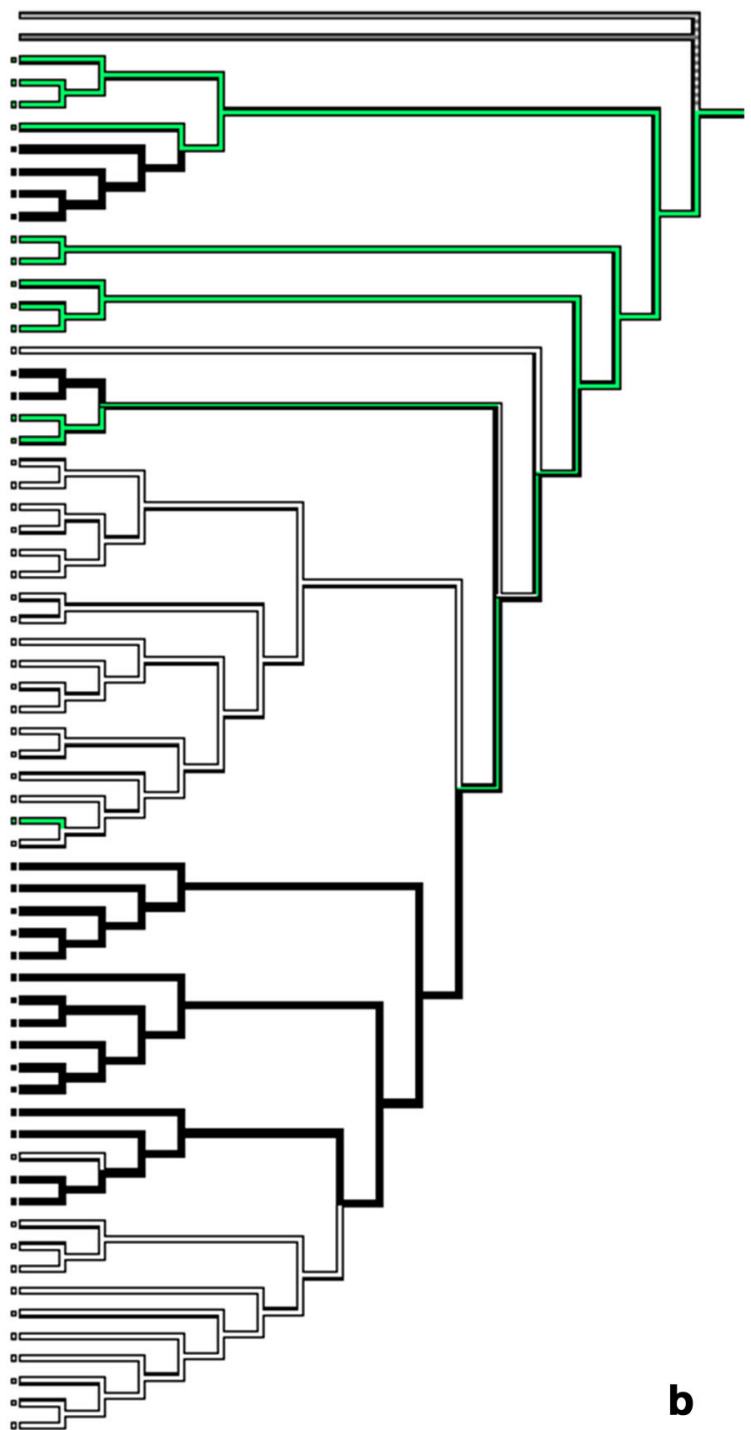

Fig. 16 Total evidence tree (Bayesian inference analysis) taken from Bond et al. (2012) where was mapped: a presence of sticky scopulae (black), absence (white); b lifestyle condition: trap-door (black),

show more developed scopulae than terrestrial species. However, the great majority of mygalomorph species are terrestrial or burrowers and only less than $20 \%$ of species are not ground dwellers (some theraphosids and migids). We also found adhesive setae in some sheet/funnel-weavers and wafer-lid trapdoor spiders such as: Cyrtaucheniidae, Diplurinae, Euctenizidae and Nemesiidae, which are not expected to have them Lapinski et al. (2015). Consequently, an interesting question remains: why mostly terrestrial species have so effective adhesion mechanisms? Considering many cursorial mygalomorphs inhabit tropical forests exposed to periodical water flooding (Junk 1997) adhesion for locomotion could have evolved to facilitate climbing on vertical components as a response to flooding stress. funnel/sheet weavers (green) and burrower/cursorial or thin wafer lid trapdoor condition (white)

\section{Non adhesive setae and pseudoscopula}

We found non microtriched setae forming a pseudoscopula mostly in trapdoor spiders and weavers, clearly differing from scopula and claw tuft setae reported for Araneomorphae and also from other Mygalomorphae. Since they lack microtrichia we interpret them as non adhesive. Similar non adhesive setae were reported by Foelix et al. (2010) for male Idiops pylorus Schwendinger 1991 and Foelix and Chu-Wang (1975), Barth (1970, 2001) and Ramírez (2014) for araneomorphs; and interpreted that they should have chemosensory functions. In the araneomorphs they are placed on dorsal side of palpal tarsus (Ramírez 2014) and seem not to be homologous with those of mygalomorphs. However, based in the comparison with the 

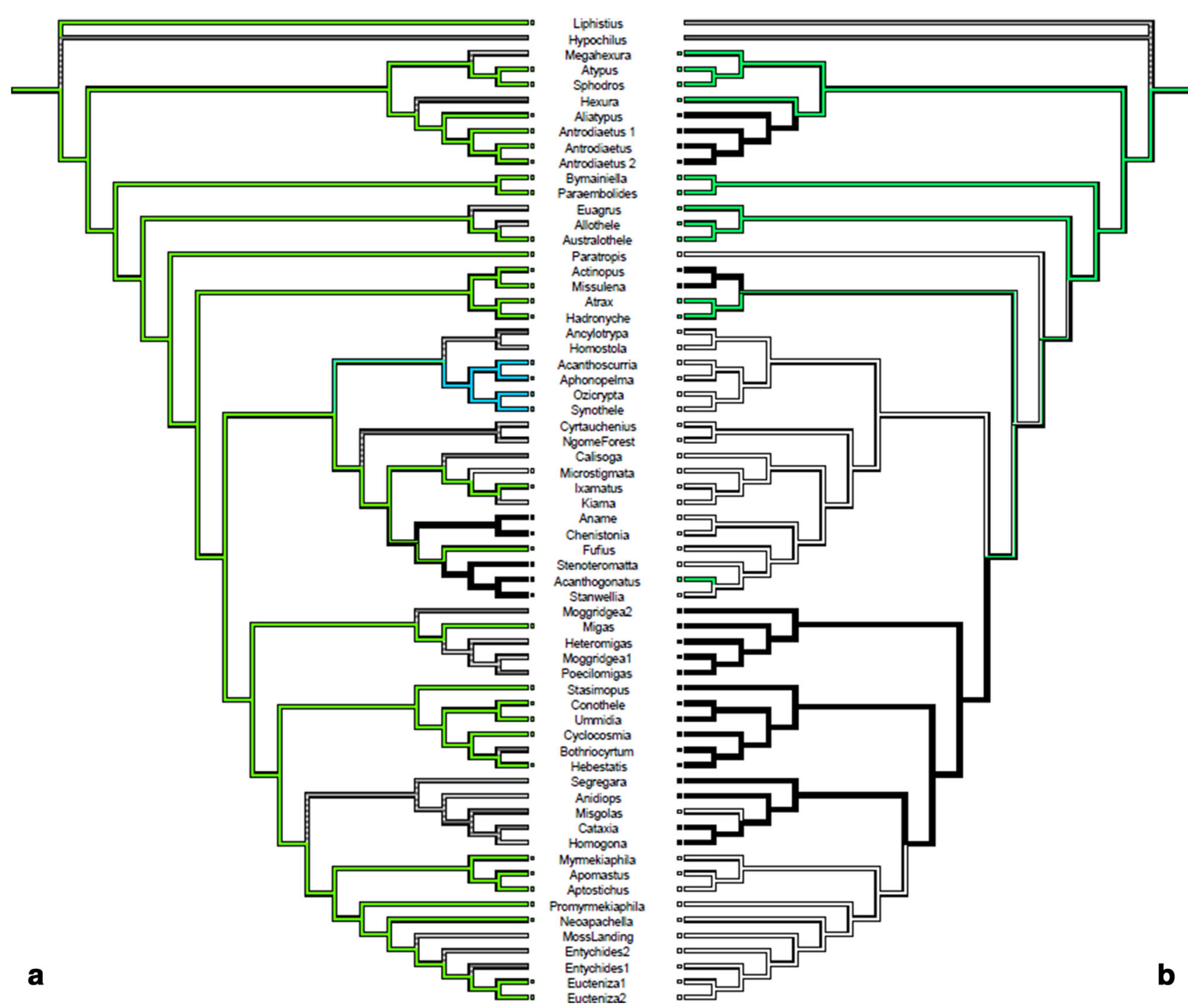

Fig. 17 Total evidence tree (Bayesian inference analysis) taken from Bond et al. (2012) where was mapped: a males, absence of sticky setae or pseudoscopula (white); adhesive scopula present (light blue), pseudoscopula present (green) scopula and pseudoscopula mixed

morphology we observed, we agree with the chemosensory function. They have sexual differences and their presence is clearly biased to males, probably to track females as in the araneomorphs (Tietjen and Rovner 1980). There is a factor that makes us propose an additional function for these setae: in some groups (e.g. Actinopodidae) setae show an important anterior-posterior gradation and furthermore, they could be extremely numerous (Foelix et al. 2010 counted 1750 in a tarsus IV of Liphistius). This fact suggests the propulsion as an additional function for these setae.

In this context, we propose an additional hypothetical function for non adhesive setae as contributing to the copulation position. Mygalomorph spiders exhibit almost the same copulation position (Baerg 1928; Costa and Pérez- (black); b lifestyle condition: trap-door condition (black), funnel/ sheet weavers (green) and burrower/cursorial or thin wafer lid trapdoor condition (white)

Miles 1998, 2002; Coyle 1971, 1985; Coyle and Shear 1981; Ferretti and Ferrero 2008; Ferretti et al. 2011, 2012, 2013; Raven 1988). They mate face to face and males extend their palps under the female. Most males have clasping structures on chelicerae or anterior legs to grasp and hold the female during mating and as security mechanism to prevent female attacks. Usually after clasping, the male pushes the female, raises and holds her and extends his palps. In that position, most of the weight of the couple is supported by posterior legs of the male on the ground.

In experimental conditions when a loose substrate is used, male posterior legs can slip and frequently the couple lose their equilibrium (Costa and Pérez-Miles 2002). This copulatory position shows that support, mainly in male posterior legs, plays a key role in Mygalomorph mating and 


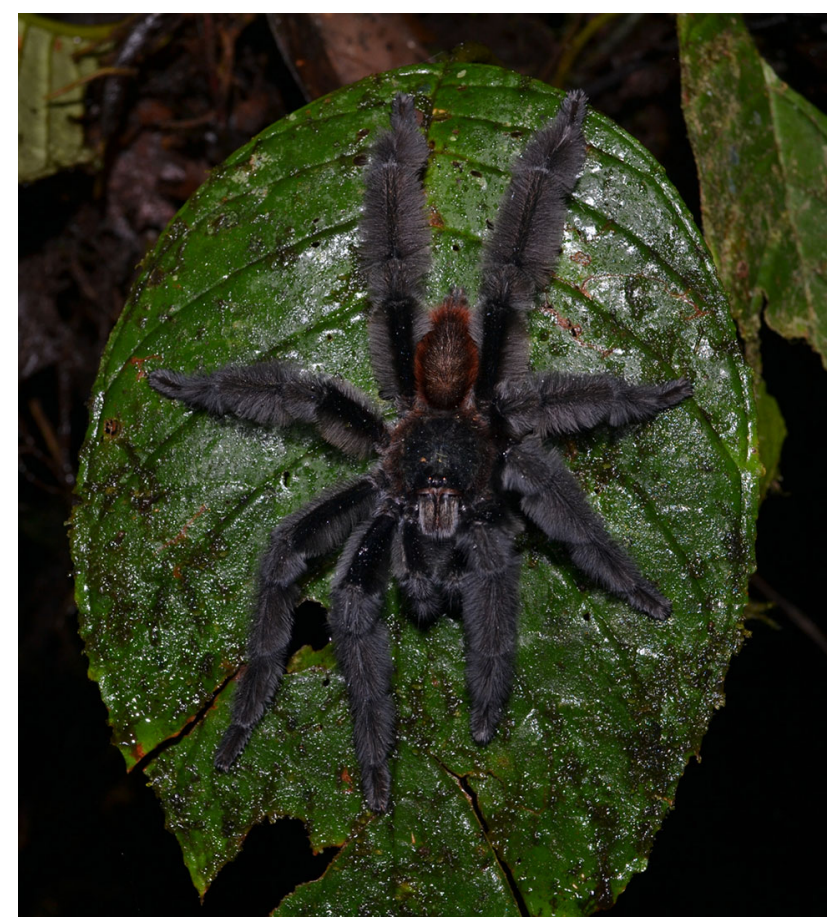

Fig. 18 Male Psalmopoeus ecclesiasticus resting on a vertical leave, head down

could be an important evolutionary pressure for their widespread presence in the group. In that sense, only male pairs III and IV present pseudoscopula in antrodiaetids and actinopodids, only males present pseudoscopula in Ctenizidae and some idiopids. Our results suggest the hypothesis that the presence of these setae in Mygalomorphae probably originally evolved as sensorial organs and was secondarily used to help the equilibrium of the couple in the copulation position. Species which lost most of these setae probably compensated the propulsion with the median band of conical setae (divided scopulae) as explained in Pérez-Miles (1994).

\section{Phylogeny of adhesive scopula, claw tufts and pseudoscopula}

Our results suggest two scenarios for the origin of adhesive scopula in the Mygalomorphae (Fig. 16): (1) two independent acquisitions of adhesive scopula in Crassitarsae and Euctenizoidina with few generic reversions or (2) its acquisition in the Bipectina with a reversion in the Ctenizoidina, but this group was considered as paraphyletic in the total evidence tree of Bond et al. (2012). As was suggested by Bond and Opell (2002), the adhesive scopula of Theraphosidae and Cyrtaucheniidae is not homologous. Our character tracking agrees with their interpretation, but suggests that the scopula in more comprehensive groups (Crassitarsae and Euctenizoidina) could not be homologous. Consequently the second hypothesis seems to be incongruent.

The scopula is associated mainly with cursorial/burrower lifestyle and free hunter habits which could indicate they are important factors of evolutionary pressure for the development of that feature; however, the presence in $\mathrm{Di}$ plura, Trechona and Linothele, and euctenicids remains obscure. The claw tufts are much more restricted in Mygalomorphae than in Araneomorphae. They are present in Theraphosidae and Barychaelidae with a parallelism in Melloina, but in this last without scopula. Claw tufts seem to be acquired twice, just in cursorial/burrower spiders. We agree with the polarity proposed by Wolff et al. (2013) that claw tufts were derived from scopula; furthermore we think that mygalomorph claw tufts are a distal specialization of the scopula. Following this reasoning, the rotation of adhesive face in distal scopula found in non claw-tufted families could be an additional evidence.

The enigmatic presence of claw tufts but no scopula in Melloina (Paratropididae) probably represent an independent acquisition considering the other Paratropididae lack scopula and claw tufts; however, the taxonomic position of this genus must be revised. Unexpectedly Myrmekiaphila (Euctenizidae) and Euoplos (Idiopidae) with pseudoscopula also presented an apical group of scopular adhesive setae on tarsi. These setae have a similar orientation of adhesive face of claw tuft setae in other mygalomorphs (Theraphosidae, Barychelidae).

Similar setae to those we found composing the pseudoscopula were reported to Liphistius and Idiops pylorus by Foelix et al. (2010). The presence of pseudoscopula in Liphistidae and widespread in several families here studied suggests could be an ancestral condition in Mygalomorphae. Probably the ancestral Mygalomorphae were trapdoor spiders or sheet-weavers and the acquisition of adhesive pads was driven by the shift to burrower/cursorial habits. Our results suggest that scopula has been independently acquired by Crassitarsae and Euctenizidae, and its association with the burrower or cursorial lifestyle indicates that probably evolved together with ecological characteristics. Adhesive setae seem to be involved both in prey capture and adhesion for locomotion to the substrate. Our main finding, the pseudoscopula, has probably an important chemosensory function but could also be involved in mechanical traction.

Acknowledgements This research was funded by Comisión Sectorial de Investigación Científica (CSIC), Universidad de la República, Uruguay, CSIC I+D [C609-348] and also by Conselho Nacional de Desenvolvimento Científico e Tecnológico (CNPq) [479377/2012-0]. We greatly thank Witold Lapinski and Jonas Wolff for the exhaustive revision of an early version of this manuscript. Laura Montes de Oca is thanked for providing us photos of some species and Nelson Ferretti for the loan of specimens. We also thank two anonymous reviewers for valuable suggestions and critiques. $\mathrm{CP}$ thanks Agencia Nacional de Investigación e Innovación (ANNI), Uruguay, for the 
financial support under postgraduate scholarship POS_NAC_2011_1_3624 code.

\section{References}

Baerg WJ (1928) The life cycle and mating habits of the male tarantula. Q Rev Biol 3:109-116

Barth FG (1970) Die Feinstruktur des Spinneninteguments. II. Die räumliche Anordnung der Mikrofasern in der lamellierten Cuticula und ihre Beziehung zur Gestalt der Porenkanäle (Cupiennius salei Keys., adult, häutungsfern, Tarsus). Z Zellforsch 104:87-106

Barth FG (2001) Sinne und Verhalten: aus dem Leben einer Spinne. Springer, Berlin

Bond JE, Opell BD (2002) Phylogeny and taxonomy of the genera of south-western North American Euctenizinae trapdoor spiders and their relatives (Araneae: Mygalomorphae, Cyrtaucheniidae). Zool J Linn Soc-Lond 136:487-534

Bond JE, Hendrixson BE, Hamilton CA, Hedin M (2012) A reconsideration of the classification of the spider infraorder Mygalomorphae (Arachnida: Araneae) based on three nuclear genes and morphology. PLoS One 7:e38753

Cardoso P, Pekár S, Jocqué R, Coddington JA (2011) Global patterns of guild composition and functional diversity of spiders. PLoS One 6(6):e21710. doi:10.1371/journal.pone.0021710

Costa FG, Pérez-Miles F (1998) Behavior, life cycle and webs of Mecicobothrium thorelli (Araneae, Mygalomorphae, Mecicobothriidae). J Arachnol 26:317-329

Costa FG, Pérez-Miles F (2002) Reproductive biology of Uruguayan theraphosids (Araneae, Theraphosidae). J Arachnol 30:571-587

Coyle FA (1971) Systematics and natural history of the mygalomorph spider genus Antrodiaetus and related genera (Araneae: Antrodiaetidae). Bull Mus Comp Zool 141:269-402

Coyle FA (1985) Observations on the mating behaviour of the tiny mygalomorph spider, Microhexura montivaga Crosby \& Bishop (Araneae, Dipluridae). Bull Br Arachnol Soc 6:328-330

Coyle FA, Shear WA (1981) Observations on the natural history of Sphodros abboti and Sphodros rufipes (Araneae, Atypidae), with evidence for a contact sex pheromone. J Arachnol 9:317-326

Dunlop JA (1994) Movements of scopulate claw tufts at the tarsus tip of a tarantula spider. Neth J Zool 45:513-520

Eggs W, Wolff JW, Khun-Nentwig L, Gorb SN, Nentwig W (2015) Hunting without a web: how lycosoid spiders subdue their prey. Ethology 121:1166-1177

Ferretti N, Ferrero A (2008) Courtship and mating behavior of Grammostola schulzei (Schmidt 1994) a burrowing tarantula from Argentina. J Arachnol 36:480-483

Ferretti N, Pompozzi G, Pérez-Miles F (2011) Sexual behavior of Acanthogonatus centralis (Araneae: Mygalomorphae: Nemesiidae) from Argentina, with some notes on their burrows. J Arachnol 39:533-536

Ferretti N, Pompozzi G, Copperi S, Pérez-Miles F, González A (2012) Copulatory behavior of Microstigmatidae (Araneae: Mygalomorphae): a study with Xenonemesia platensis from Argentina. J Arachnol 40:252-255

Ferretti N, Pompozzi G, Copperi S, Pérez-Miles F (2013) Sexual behaviour of mygalomorph spiders: when simplicity becomes complex; an update of the last 21 years. Arachnology 16(3):85-93

Foelix RF (2011) Biology of spiders. Oxford University Press, New York

Foelix RF, Chu-Wang IW (1975) The structure of scopula hairs in spiders. In: Proceedings of the 6th international arachnological Congress. Amsterdam, pp 56-58
Foelix RF, Jackson RR, Henksmeyer A, Hallas S (1984) Tarsal hairs specialized for prey capture in the salticid Portia. Rev Arachnol 5:329-334

Foelix RF, Erb B, Michalik P (2010) Scopulate hairs in male Liphistius spiders: probable contact chemoreceptors. J Arachnol 38:599-603

Foelix RF, Rast B, Erb B (2012) Hafthaare bei Vogelspinnen: Vergleich einer bodenlebenden Brachypelma mit einer baumlebenden Poecilotheria. Arachne 6:16-23

Guadanucci JPL (2005) Tarsal scopula significance in Ischnocolinae phylogenetics (Araneae, Mygalomorphae, Theraphosidae). J Arachnol 33:456-467

Hill DE (1977) The pretarsus of salticid spiders. Zool J Linn Soc 60:319-338

Homann H (1957) Haften Spinnen an einer Wasserhaut? Naturwissenschaften 44:318-319

Jocqué R, Alderweireldt M (2005) Lycosidae: the grassland spiders. In: Deltshev C, Stoev P (eds) European Colloquium of Arachnology 2005, Blagoevgrad, Bulgaria, Acta Zool Bulg, Suppl No.1. Institute of Zoology and National Museum of Natural History, Bulgarian Academy of Sciences, pp 125-130

Jocqué R, Dippenaar-Schoeman AS (2007) Spider families of the world. Royal Museum for Central Africa, Tervuren

Junk WJ (1997) The central amazonian floodplain: ecology of a pulsing system. Ecological studies, vol 126. Springer, Berlin

Keane PN, Hovgaard MB, Mostaert AS, Jarvis SP (2012) Asymmetric spatula heads combined with lateral forces provide a mechanism for controlling the adhesive attachment of a range of spider species. J Adhes Sci Technol 28(3-4):256-272

Kesel AB, Martin A, Seidl T (2003) Adhesion measurements on the attachment devices of the jumping spider Evarcha arcuata. J Exp Biol 206:2733-2738

Kesel AB, Martin A, Seidl T (2004) Getting a grip on spider attachment: an AFM approach to microstructure adhesion in arthropods. Smart Mater Struct 13:512-518

Keyserling E (1877) Ueber amerikanische Spinnenarten der Unterordnung Citigradae. Verhandlungen der Kaiserlich-Königlichen Zoologisch-Botanischen Gesellschaft in Wien 26:609-708

Labarque FM, Wolff JO, Michalik P, Griswold CE, Ramírez MJ (2017) The evolution and function of spider feet (Araneae: Arachnida): multiple acquisitions of distal articulations. Zool J Linnean Soc 20:1-34

Lapinski W, Walther P, Tschapka M (2015) Morphology reflects microhabitat preferences in an assemblage of Neotropical wandering spiders. Zoomorphology. doi:10.1007/s00435-0150247-8

Maddison WP, Maddison DR (2017) Mesquite: a modular system for evolutionary analysis. Version 3.2. http://mesquiteproject.org. Accessed 1 July 2017

Montes de Oca L, Pérez-Miles F (2013) Two new species of Chaco Tullgren from the Atlantic coast of Uruguay (Araneae, Mygalomorphae, Nemesiidae). Zookeys 337:73-87

Niederegger S (2013) Functional aspects of spider scopulae. In: Nentiw W (ed) Spider Ecophysiology. Springer, Berlin

Niederegger S, Gorb S (2006) Friction and adhesion in the tarsal and metatarsal scopulae of spiders. J Comp Physiol A 192:1223-1332

Pekar S, Sobotnik J, Lubin J (2011) Armoured spiderman: morpological and behavioural adaptations of a specialised araneophagous predator (Araneae: Palpimanidae). Naturwissenschaften 98:593-603

Perafán C, Galvis W, Gutiérrez M, Pérez-Miles F (2016) Kankuamo, a new Theraphosid genus from Colombia (Araneae, Mygalomorphae), with a new type of urticating setae and divergent male genitalia. Zookeys 601:89-109 
Pérez-Miles F (1994) Tarsal scopula division in Theraphosinae (Araneae, Theraphosidae): its systematic significance. J Arachnol 22:46-53

Pérez-Miles F, Perafán C, Santamaría L (2015) Tarantulas (Araneae: Theraphosidae) use different adhesive pads complementary during climbing on smooth surfaces: experimental approach in eight arboreal and burrower species. Biol Open 4:1643-1648

Ramírez MJ (2014) The morphology and phylogeny of dionychan spiders (Araneae, Areneomorphae). Bull Am Mus Nat Hist 390:1-374

Raven RJ (1985) The spider infraorder Mygalomorphae (Araneae): cladistics and systematics. Bull Am Mus Nat Hist 182:1-180

Raven RJ (1988) Preliminary observations on the mating behaviour of the Australian mygalomorph spider Australothele jamiesoni (Dipluridae, Araneae, Arachnida). Mem Queensl Mus 25:471-474

Richards AG, Richards PA (1979) The cuticular protuberances of insects. Int J Insect Morphol Embryol 8:143-157

Ridley M (1983) The explanation of organic diversity. Blackwell Scientific Publications, Oxford

Rovner JS (1978) Adhesive hairs in spiders: behavioral functions and hydraulically mediated movement. Symp Zool Soc Lond 42:99-108

Rovner JS (1980) Morphological and ethological adaptations for prey capture in wolf spiders (Araneae, Lycosidae). J Arachnol 8:201-215

Schiapelli RD, de Gerschman P (1975) Calathotarsus simoni sp. nov. (Araneae, Migidae). Physis Revista de la Sociedad Argentina de Ciencias Naturales (C) 34:17-21

Schwendinger PJ (1991) Two new trap-door spiders from Thailand (Araneae, Mygalomorphae, Idiopidae). Bull Br Arachnol Soc $8: 233-240$
Simon E (1889) Etudes arachnologiques. 21e Mémoire. XXX. Descriptions de quelques arachnides du Chili et remarques synonymiques sur quelques unes des espèces décrites par Nicolet. Ann Soc entomol Fr 8(6):217-222

Simon E (1892) Histoire Naturelle des Araignées, vol 1, Paris, pp 1-256

Tietjen WJ, Rovner JS (1980) Trail-following behaviour in two species of wolf spiders: sensory and etho-ecological concomitants. Anim Behav 28:735-741

Varenberg M, Pugno NM, Gorb SN (2010) Spatulate structures in biological fibrillar adhesion. Soft Matter 6:3269-3272

Wohlfart E, Wolff JO, Arz E, Gorb SN (2014) The whole is more than the sum of all its parts: collective effect of spider attachment organs. J Exp Biol 217:222-224

Wolff JO, Gorb SN (2012a) Comparative morphology of pretarsal scopulae in eleven spider families. Arthropod Struct Dev 41:419-433

Wolff JO, Gorb SN (2012b) The influence of humidity on the attachment ability of the spider Philodromus dispar (Araneae, Philodromidae). Proc R Soc B 279:139-143

Wolff JO, Gorb SN (2013) Radial arrangement of Janus-like setae permits friction control in spiders. Scientific Reports. doi:10. 1038/srep01101

Wolff JO, Gorb SN (2015) Adhesive foot pads: an adaptation to climbing? An ecological surveyin hunting spiders. Zoology 118:1-7

Wolff JO, Gorb SN (2016) Tape- and spatula-shaped microstructures. In: Wolff JO, Gorb SN (eds) Attachment structures and adhesive secretions in arachnids, Springer, Biologically-Inspired Systems 7, Switzerland, pp 53-30. doi:10.1007/978-3-319-45713-0_3

Wolff JO, Nentwig W, Gorb SN (2013) The great silk alternative: multiple co-evolution of web loss and sticky hairs in spiders. PLoS One 8:1-13 